A..FEDDERSEN / W. MAENNIG MEGA-EVENTS ANDSECTORAL EMPLOYMENT: THE CASE OF THE 1996 OLYMPIC GAMES

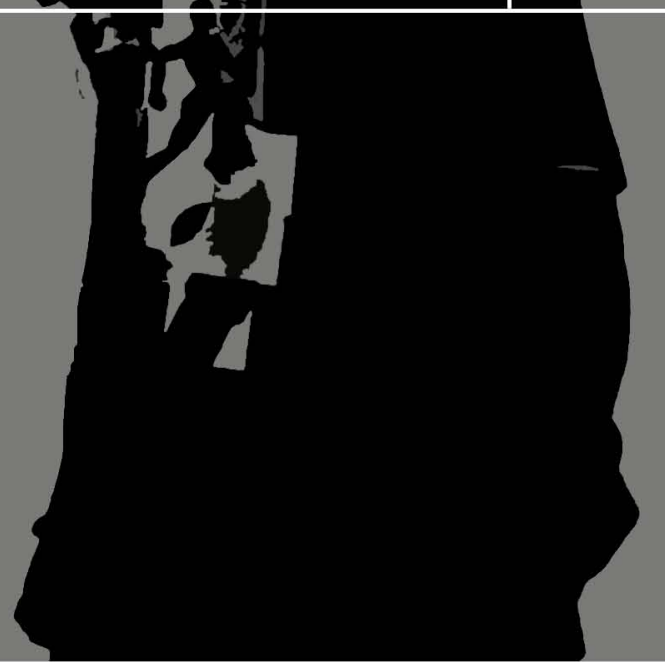


Hamburg Contemporary Economic Discussions

University of Hamburg

Faculty Economics and Social Science

Chair for Economic Policy

Von-Melle-Park 5

D-20146 Hamburg | Germany

Tel $+494042838-4622$

$\mathrm{Fax}+494042838-6251$

http://www.uni-hamburg.de/economicpolicy/

Editor: Wolfgang Maennig

Arne Feddersen

University of Hamburg

Faculty Economics and Social Science

Chair for Economic Policy

Von-Melle-Park 5

D-20146 Hamburg | Germany

Tel $+494042838-4628$

Fax $+494042838-6251$

feddersen@econ.uni-hamburg.de

Wolfgang Maennig

University of Hamburg

Faculty Economics and Social Science

Chair for Economic Policy

Von-Melle-Park 5

D-20146 Hamburg | Germany

Tel $+494042838-4622$

$\mathrm{Fax}+494042838-6251$

maennig@econ.uni-hamburg.de

ISSN 1865 - 2441 (Print)

ISSN 1865 - 7133 (Online)

ISBN 978 - 3 - 940369 - 84 - o (Print)

ISBN $978-3-940369-85-7$ (Online) 


\title{
Mega-Events and Sectoral Employment: The Case of the 1996 Olympic Games
}

\begin{abstract}
This paper contributes to the analysis of large sporting events using highly disaggregated data. We use the 1996 Olympic Games in Atlanta, which are also outstanding as one of the very few large sporting events where ex post academic analysis found significant positive effects. This paper extends earlier studies in several ways. First, monthly rather than quarterly data will be employed. Second, the impact of the 1996 Olympics will be analyzed for 16 different sectors or subsectors. Third, in addition to standard DD models, we use a non-parametric approach to flexibly isolate employment effects. Regarding the Olympic effect, hardly any evidence for a persistent shift in the aftermath of or the preparation for the Olympic Games is supported. We find a significant positive employment effect in the monthly employment statistics exclusively during the staging of the Olympic Games (July 1996). These short-term effects are concentrated in the sectors of "retail trade", "accommodation and food services", and "arts, entertainment, and recreation", while other sectors showed no such effects.

Keywords: Olympic Games, Economic Impact, Ex-post Analysis, Employment, Sectoral Data

JEL classification: H54; R12; L83
\end{abstract}

Version: March 2010

\section{Introduction}

The vast majority of ex post analyses in the last two decades suggest that sports franchises, facilities, and mega-events have little or no significant positive effect on aggregated wages, income and/or employment. In the recent past, some effort has been undertaken to use new methods, more disaggregated data or other variables. ${ }^{1}$

This paper contributes to the body of impact literature with highly disaggregated data using the case of the 1996 Olympic Games in Atlanta, which are also outstanding in being one of the very few large sporting events where ex post analysis has found significant positive effects: HOTCHKISS, MOORE, \& ZOBAY (2003) isolate a boost of employment by $17.2 \%$ in Georgia counties affiliated with and

1 For example, BAADE, BAUMANN, \& MATHESON (2008a, 2008b) and Coates (2006) use taxable sales data, while BAUMANN, MATHESON, \& MUROI (2009) use daily flight data. 
close to Olympic activities. This level shift can be translated into roughly 293,000 additional jobs that resulted from the Olympic Games. ${ }^{2}$ Furthermore, as a second key result, they report a positive and significant trend shift caused by the 1996 Olympics of additional 0.2 percentage points for their Olympic treatment group in comparison with the other counties in Georgia. BAADE \& MATHESON (2002) estimate employment gains that ranged from 3,500 to 42,500 additional jobs. This paper extends these two studies in several ways. First, monthly rather than quarterly data will be employed. Second, the impact of the 1996 Olympics will be analyzed for 16 different employment sectors or subsectors. Third, in addition to standard Difference-in-Difference (DD) models, we use a non-parametric approach to flexibly isolate employment effects.

The remainder of the paper is organized as follows. Section 2 provides an extensive literature review as well as some methodological remarks. Section 3 describes the background of the 1996 Olympics and introduces the data. In section 4 , the empirical strategy is presented. The results for the aggregated employment data are provided in section 5 , while the results for sector-specific employment data can be found in section 6 . Finally, section 7 concludes.

\section{Literature Review and Methodological Issues}

According to BAADE, BAUMANN, \& MATHESON (2010), identifying the economic impacts of sports franchises, stadiums, and mega-events is equivalent to trying to uncover the proverbial needle in the haystack. Almost all ex post studies conclude that mega-sporting events like the Olympic Games or the FIFA World Cup do not exert any significant impact on economic indicators (e.g., GDP) at the country lev-

\footnotetext{
As their model is semi-logarithmic, the coefficients are biased according to HALVORSEN \& PALMOUIST (1980) and should be corrected. For a parameter $b$, the percentage effect is equal to $e^{b}-1$. Accounting for this bias, the employment boost estimated by HOTCHKISS, MOORE, \& ZOBAY (2003) is even higher at $18.8 \%$, which could be translated into 324,000 additional jobs in their treatment area.
} 
el. ${ }^{3}$ This might be due to the size of the host countries. For example, KURSCHEIDT, PREUß, \& SCHÜTTE (2008), using poll data, estimate an impact of the 2006 FIFA World Cup in Germany through substitution-adjusted consumer spending of $€ 3.2$ billion. At first glance, this seems to be an impressive figure, but compared with Germany's GDP in 2006 of $€ 2,325$ billion, only a small relative impact of $0.14 \%$ remains. A similar example can be found in BAADE, BAUMANN, \& MATHESON (2010, p. 4). Here, an average Super Bowl-led boost of US\$300 million, as assumed by the NFL, is translated into $0.1 \%$ of the annual personal income within a large metropolitan statistical area (MSA). Bearing this in mind, it could be concluded that any positive impact of a mega-event will almost certainly be lost within normal fluctuations in the economy and, from a statistical point of view, will disappear in the white noise. This effect will be stronger as the data become more aggregated. Reverting to the above-mentioned simile, the haystack is too large to isolate the needle. Several strategies exist to deal with this problem. Common to these strategies is that the data have to be more disaggregated. Attempts have been made to achieve disaggregation of the data on four scales: (1) on a regional scale; (2) on the scale of the target variable; (3) on an industry scale; and (4) on a time scale.

(1) If the effects of a mega-event are very localized, then examining smaller administrative units such as counties or cities can provide additional insights. Most regionalized studies employ data on the US Metropolitan Statistical Area (MSA) level, including BAADE \& DYE (1988, 1990), BAADE \& MATHESON (2001, 2002, 2004), COATES \& HUMPHREYS (1999, 2002, 2003), DAVIS \&END (2010), LERTWACHARA \& COCHRAN (2007), MATHESON (2005), NELSON (2001), and SANTO

To mention some of the few exceptions, aside from the two above-mentioned Atlanta studies, ALLMERS \& MAENNIG (2009) find a significant but small increase in the number of overnight stays of foreigners during the World Cup 2006 in Germany. CARLINO \& COULSON (2004) report that the presence of an NFL franchise in a city increases rents in the central city by about $8 \%$. JASMAND \& MAENNIG (2008) find some significant income effects of the Olympic Games in Munich in 1972. STERKEN (2006) finds a stimulating effect of the Olympic Games on per capita GDP growth but finds no effect of the FIFA World Cup. Notably, BAIM (1994, pp. 183-194) estimates that a large city with more than 3 million inhabitants will gain 620,000 jobs in the presence of both an NFL and an MLB franchise. See COATES \& HUMPHREYS (2008) for a literature survey, especially of the literature on the USA. 
(2005). Smaller geographic units like counties are used by, for example, HOTCHKISS, MOORE, \& ZOBAY (2003) and JASMAND \& MAENNIG (2008), whereas city-level data are employed by FEDDERSEN, GRÖTZINGER, \& MAENNIG (2009), GIUS \& JOHNSON (2001), HAGN \& MAENNIG (2008, 2009), COATES \& DEPKEN II (2006), and CARLINO \& COULSON (2004). Only a few analyses exist that use data at the sub-city level; examples of these are studies by AHLFELDT \& MAENNIG (2008, 2009), COATES \& HUMPHREYS (2006), and TU (2005).

(2) The three most popular target variables are income, wages, and employment. As the results for these "classical" data are sobering from the booster's perspective and to preserve academic impartiality, the focus of the research was switched to other data that might be more appropriate for the measurement of economic impact. As a result, a growing body of impact studies exists that makes use of other data, such as taxable sales (BAADE, BAUMANN, \& MATHESON, 2008a, 2008b; COATES, 2006; COATES \& DEPKEN II, 2006; LEEDS, 2008; PORTER, 1999), hotel occupancy rates (LAVOIE \& RODRIGUEZ, 2005; PORTER \& FLETCHER, 2008), tourists' overnight stays (ALLMERS \& MAENNIG, 2009), housing rents (CARLINO \& COULSON, 2004; COATES \& MATHESON, 2009), real estate prices (AHLFELDT \& MAENNIG, 2008, 2009; TU, 2005), and flight arrivals (BAUMANN, MATHESON, \& MUROI, 2009). In addition, steps in the direction of identifying intangible effects of mega-events have been taken. KAVETSOS \& SZYMANSKI (2009), for example, analyze the effect of hosting a mega-event as well as the success of national athletes at mega-events on subjective well-being.

(3) It is widely accepted that mega-events may have a stronger impact on, for example, service-related industries than on the mining or utility industry. The strongly impacted sectors may include food services and hospitality as well as the retail trade. For example, BAADE (1996), BAADE, BAUMANN, \& MATHESON (2008a, 2008b), BAADE \& DYE (1988), BAADE \& SANDERSON (1997), BAIM (1994), COATES \& HUMPHREYS (2003), LEEDS (2008), and MILLER (2002) analyze sectorally differentiated data.

(4) As almost all mega-events have a maximum duration of two to four weeks, impacts might only be present in a narrow time span. Using aggregated data such 
as annual or quarterly data carries the risk that the event effect might be smoothed with the normal variation within the data-generation process. This rule is absolutely relevant in the case of the analysis of a mega-event but loses trenchancy if the existence of a sports franchise is the variable of interest. The absolute majority of scholarly studies employ annual data. Data on a quarterly basis are used by BAADE, BAUMANN, \& MATHESON (2008b) and HOTCHKISS, MOORE, \& ZOBAY (2003) and monthly data by ALLMERS \& MAENNIG (2009), BAADE, BAUMANN, \& MATHESON (2008a, 2010), COATES (2006), COATES \& DEPKEN II (2006), HAGN \& MAENNIG (2009), LAVOIE \& RODRIGUEZ (2005), and LEEDS (2008). BAUMANN, MATHESON, \& MUROI (2009) are the only researchers to use daily data.

After categorizing the existing literature according to the degree of data disaggregation, one important methodological challenge remains to be discussed. Any analysis of the economic impact of sports franchises, stadiums, and mega-events has to deal with one major concern: the counterfactual. First, one might ask what would have happened if the (public) money had been used for an alternative investment. Second, one might ask if the observed impact is really caused by the treatment or if a merely coincidental macroeconomic shock is detected. In the sports impact literature, two main lines of research have been established, each dealing with one of these issues. Dealing with the first kind of counterfactual, BAADE \& MATHESON (2001), COATES \& HUMPHREYS (2002), and MATHESON (2005), among others, use panel data and growth models to compare the predicted and observed values of economic indicators. The second group of ex post analyses, including FEDDERSEN, GRÖTZINGER, \& MAENNIG (2009), HAGN \& MAENNIG (2008, 2009), HOTCHKISS, MOORE, \& ZOBAY (2003), and JASMAND \& MAENNIG (2008), use DD approaches to isolate the impact of sports stadiums and events from pure macroeconomic shocks using other geographic units as a control group. Both approaches depend on the assumption that a stable relationship between the predicted counterfactual and the true (not observable) counterfactual exists. However, even if this assumption does not apply completely, these approaches are preferable because the bias when ignoring counterfactuals is definitely stronger than it is if the predicted counterfactual is not exactly matched. 
Finally, the research design of this study should be situated within the context of the existing literature. We analyze employment data for the state of Georgia, USA, and try to reduce the size of the metaphorical haystack in several ways. First, data differentiated by industry classifications will be used. Furthermore, the frequency of the available data is monthly. Finally, spatially comprehensive countrylevel data are used. As mentioned above, some literature employing sectoral or monthly data already exists. However, to the knowledge of the authors, none of the studies based on employment make use of monthly and regionalized data. In addition to conventional DD analysis, we also use a partially non-parametric model.

\section{Background and Data}

The (centennial) Games of the XXVI Olympiad were held in Atlanta, Georgia, USA, from July 19 to August 4, 1996. Overall, 197 National Olympic Committees with 10,318 athletes took part in 271 sports events. Over 15,000 media representatives and 47,000 volunteers were registered (IOC, 2010). A record-breaking 8.6 million tickets were sold (LA84 FOUNDATION, 2010). During the 17 days of the Olympic Games, more than 2 million visitors came to Atlanta, and an estimated 3.5 billion people around the world watched the sports events on television. The preparations for the Games were intense; many of the sports venues were expanded or newly built. The financing for the 1996 Olympics came from a variety of sources, including more than US\$1 billion in public money as well as ticket sales, corporate sponsorships and donations by the IOC. Also, approximately 7,500 hotel rooms were built between 1990 and 1996, raising the total number of hotel rooms within the Atlanta area to more than 60,000 (NGE, 2010). The 271 events were staged in 27 venues, of which 22 were located within the state of Georgia, while the remaining five 5 venues, which hosted matches of the Olympic men's and women's soccer tournaments, were located in other states (Alabama, Florida, Tennessee, and the District of Columbia). The 22 Georgia venues lay within 9 different counties. The "Olympic Center" was located in the city of Atlanta and thus in Fulton County, while some special events were displaced to venues providing the needed 
infrastructure (e.g., sailing and yachting in Savannah/Chatham County). Figure 1 displays the geographical distribution of the Olympic venues.

Fig. 1 Venues of the 1996 Olympic Games

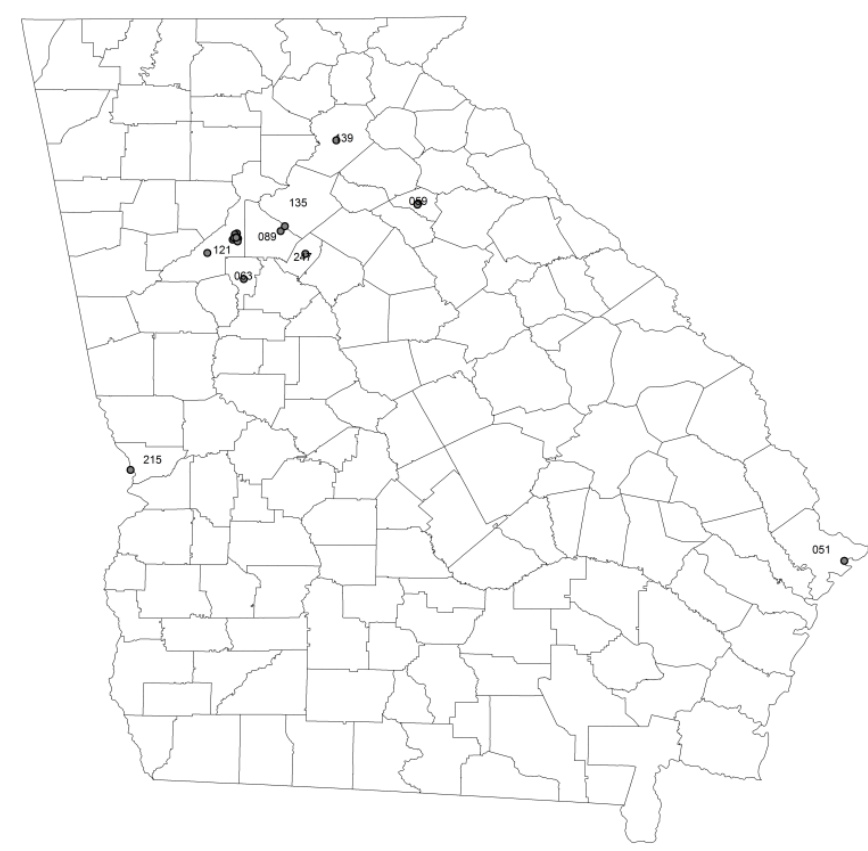

Notes: Gray circles are Olympic venues within Georgia (see Table 1). Venue counties are labeled with their FIPS county codes.

Monthly data on employment for each county in Georgia were obtained from the Quarterly Census of Employment and Wages (OCEW) as provided by the Bureau of Labor Statistics (BLS). ${ }^{4}$ The data are available from January 1990 to December 2008. The observation period thus spans 228 months. In comparison with most other empirical impact analyses based on annual or quarterly data, this is a substantial gain in detail. To further reduce the size of the haystack, we use employment figures disaggregated by industries. Two different industry classification schemes exist: the Standard Industrial Classification (SIC) and the North American Industry Classification System (NAICS). Due to a change in the industry classification system from SIC to NAICS in 1997, some data issues have to be considered. SIC-based data start in 1985 and are available on a quarterly basis until the last

4 The OCEW data are based on place of employment rather than place of residence (BUREAU OF LABOR STATISTICS, 2010). 
quarter of 2000. The first available data for the NAICS classification are from January 1990, and NAICS data have been published continuously on a monthly basis since that time. Because the NAISC scheme is more disaggregated than the SIC scheme and some reorganizations have been made, it is not possible to convert data from both sources to a common data set. Due to the fact that (1) the time series for the NAICS-based employment data is much longer than the corresponding SIC-based time series and (2) monthly data (NAICS) are supposed to be more suitable for analyzing the Olympic impact than quarterly data (SIC), we use NAICS employment data provided by the BUREAU OF LABOR STATISTICS (2009). Consequently, aside from aggregated data for all industries, data divided into subsamples according to two- to four-digit industry classifications by the NAICS tableau will be used as the dependent variable in the empirical analysis.

At first glance, two-digit main sectors can be employed for the empirical analysis. ${ }^{5}$ Furthermore, we identified several three-digit subsectors that will also be worthwhile targets of analysis due to the supposed high importance of these sectors to the Olympic Games. In particular, these subsectors are spectator-related industries such as "food and beverage stores", "accommodations", and "food services and drinking places". Aside from plausibility considerations, the choice of the analyzed sectors is mainly driven by data availability.

There are two main reasons why no data may be reported for a given month and county: (1) there were no people employed for the specific industry or (2) the data are subject to disclosure restrictions. As we need continuous data for the DD analysis, only counties with no missing data can enter the empirical analysis. ${ }^{6}$ As a result, a balanced panel has to be constructed for every subsample, and, consequently, the control group is composed of different numbers of counties. Table 1 displays the number of available counties that provide a continuous employment sequence.

5 The "public administration" sector (NAICS 92) has to be excluded because of inconsistencies in the data. In particular, in 1990 and 2000, several months showed extreme jumps in employment, with numbers sometimes quadrupling.

6 No data are available for the information sector (NAICS 51). 
Tab. 1 Availability of Continuous Time Series for Sectoral Employment Data

\begin{tabular}{llr}
\hline \hline NAICS & Industry & $\begin{array}{c}\text { Number of } \\
\text { Counties }\end{array}$ \\
\hline 10 & All Industries & 159 \\
11 & Agriculture, Forestry, Fishing, and Hunting & 30 \\
21 & Mining & 2 \\
22 & Utilities & 2 \\
23 & Construction & 95 \\
$31-33$ & Manufacturing & 119 \\
42 & Wholesale Trade & 60 \\
$44-45$ & Retail Trade & 147 \\
445 & Food and Beverage Stores & 91 \\
451 & Sporting Goods, Hobby, Book, and Music Stores & 24 \\
$48-49$ & Transportation and Warehousing & 159 \\
51 & Information & - \\
52 & Finance and Insurance & 92 \\
53 & Real Estate and Rental and Leasing & 59 \\
54 & Professional, Scientific, and Technical Services & 34 \\
55 & Management of Companies and Enterprises & 15 \\
56 & Administrative, Support, Waste Management, Remediation Services & 44 \\
61 & Educational Services & - \\
62 & Health Care and Social Assistance & 39 \\
71 & Arts, Entertainment, and Recreation & 32 \\
72 & Accommodation and Food Services & 42 \\
721 & Accommodation & 27 \\
722 & Food Services and Drinking Places & 74 \\
81 & Other Services (except Public Administration) & 90 \\
92 & Public Administration & 114 \\
\hline
\end{tabular}

Source: US CENSUS BUREAU (2010) and BUREAU OF LABOR STATISTICS (2009).

Figure 2 shows the development of overall seasonally adjusted ${ }^{7}$ employment in Georgia. The data are averaged within two different regionally distinct groups. One group, referred to as venue counties, consists of the counties that hosted at least one Olympic competition. The other group, referred to as the control group, is composed of the remaining counties of Georgia. The top panel shows the development of relative employment in both groups. Here, the data are averaged among the groups for every month and then normalized to the starting value in January 1990. The two groups showed, with the exception of a peak in the differ-

\footnotetext{
The seasonally adjusted data are calculated by a monthly dummy variable regression. After conducting these regressions, the predicted residuals were taken as seasonally adjusted time series.
} 
ence sequence from the middle to the end of 1990 , very similar relative development until the beginning of 1992. Afterwards, some divergence appears, with the gap opening more or less continuously until March 2001, when the path of development shifts and a strong convergence takes place. The middle panel depicts the difference between the group averages (difference-in-mean) and illustrates the two contrary relative developments before and after March 2001. Last, the bottom panel depicts averaged but not normalized data. It is obvious that the mean employment for the venue county group is considerably higher than the mean of the control group. The visual inspection of panels [a] and [b] finds a peak in the normalized average employment for the venue county group in July 1996, while no such peak is visible for the control group. The evidence is even clearer if one looks at the difference-in-mean sequence. Here, a peak in the difference between the two groups is evident and seems to be limited to July 1996. 
Fig. 2 Development of Seasonally Adjusted Employment (All Industries)

[a]

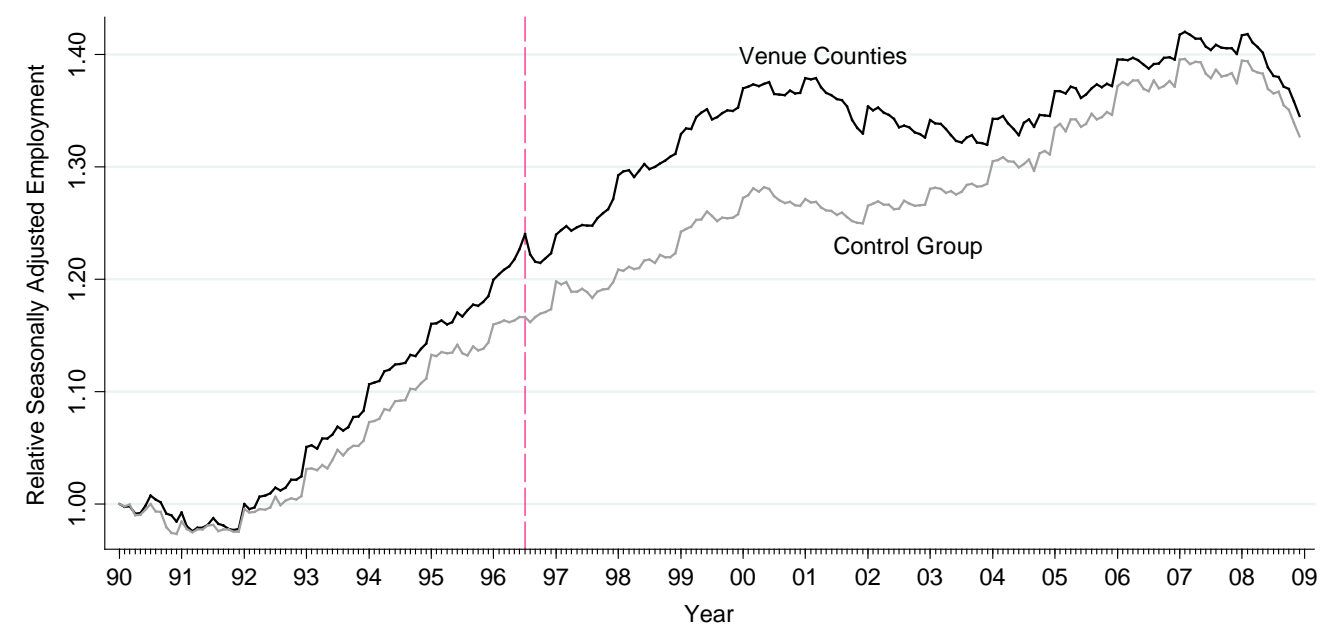

[b]

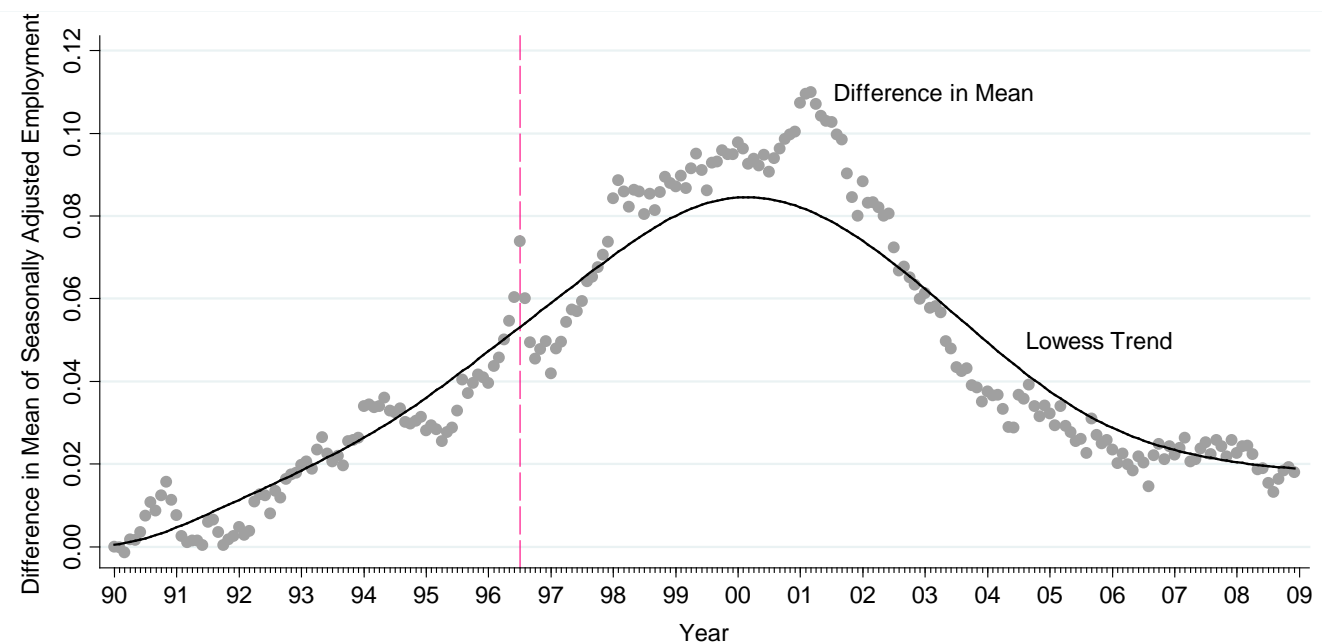

[c]

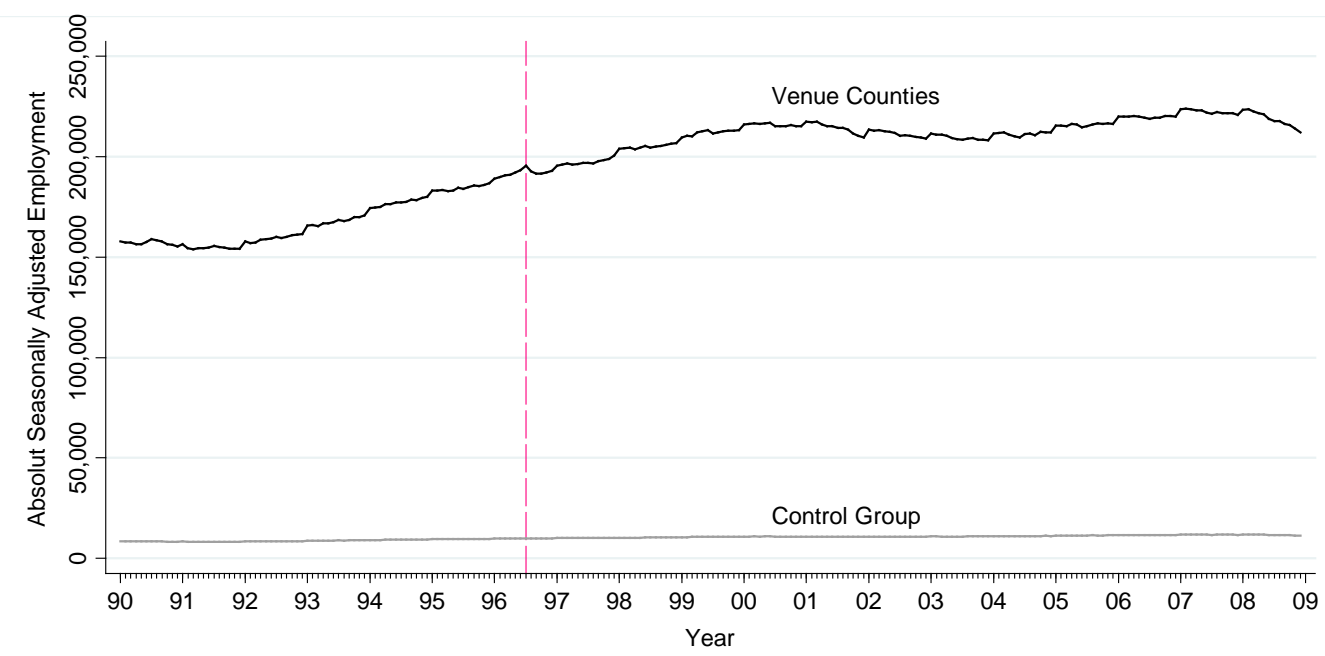

Notes: OCEW employment is seasonally adjusted by a dummy variable regression. Employment figures are arithmetic means for both groups. The vertical line marks the month of the Olympic Games (July 1996). 


\section{Empirical Strategy}

\subsection{Econometric Model}

Difference-in-difference analysis (BERTRAND, DUFLO, \& MULLAINATHAN, 2004) or regression discontinuity designs (IMBENS \& LEMIEUX, 2008) are established approaches to identify treatment effects that occur at particular locations after a specific intervention. Common to both approaches is the comparison of the difference in outcomes before and after an intervention for groups affected by the intervention to the difference for unaffected groups (BERTRAND, DUFLO, \& MULLAINATHAN, 2004). Moreover, such an analysis works best if the shock can be modeled discretionarily with respect to both location (treatment vs. control) and time (before vs. after the shock). For our analysis, we employ a method introduced by DACHIS, DURANTON, \& TURNER (2010, pp. 9-13) in another research context.

Let $t$ denote time, with $t=$ July 1996 as the intervention point, $t<$ July 1996 before the staging of the Olympic Games, and $t>$ July 1996 after. Let $i$ denote the county code within the state of Georgia according to the FIPS system. Then, two indicators based on time dimension $t$ and spatial dimension $i$ can be defined:

$$
\begin{aligned}
\chi^{P} & =\left\{\begin{array}{l}
1 \text { if } t \geq 1996 M 7 \\
0 \text { else }
\end{array}\right. \\
\chi^{V} & =\left\{\begin{array}{l}
1 \text { if } i \in v \\
0 \text { else }
\end{array}\right.
\end{aligned}
$$

That means that $\chi^{P}$ changes from zero to one in the month during which the Olympic Games were held, while $\chi^{V}$ is one if a county belongs to the treatment group $v$.

Let $e(i, t)$ denote total employment at a particular location and time. This function can then be decomposed into five parts: $(1)$ the function $l(i, t)$ is a latent employment surface that is continuous in $i$ and $t$; (2) a jump in the employment surface that occurs at the month the Olympic Games began: $\beta_{1} \chi^{P} ;(3)$ a jump in the employment surface that only takes place in the venue counties: $\beta_{2} \chi^{V} ;(4)$ an interaction effect of the former jumps: $\lambda \chi^{P} \chi^{V}$; (5) a zero-mean error term (DACHIS, DURANTON, \& TURNER (2010). 
Following this notation, employment at location $i$ and time $t$ can be written as

$$
e(i, t)=l(i, t)+\beta_{1} \chi^{P}+\beta_{2} \chi^{V}+\lambda \chi^{P} \chi^{V}+\epsilon(i, t)
$$

Using the case of $l(i, t)=l(0,0)$ it is possible to demonstrate how this strategy identifies the treatment effect of the Olympic Games in Atlanta 1996. Here, all variation in $e$ is a result of the discontinuities created by $\chi^{P}$ and $\chi^{V}$.

$$
e_{i, t}=l(0,0)+\beta_{1} \chi^{P}+\beta_{2} \chi^{V}+\lambda \chi^{P} \chi^{V}+\epsilon_{i, t}
$$

Equation (2) is the simplest specification that permits detecting the discontinuity caused by the Olympic Games; it is more or less equal to the regression from HOTCHKISS, MOORE, \& ZOBAY (2003). Two main problems arise when estimating equation (2). First, the assumption that $l$ is constant with respect to $i$ and $t$ seems to be restrictive and might only be correct for a small region around $l(0,0)$. If a larger variation of the surface $l(i, t)$ is analyzed, variation of the latent employment surface can no longer be ignored. Consequently, equation (4) has to be reformulated:

$$
e_{i, t}=l(0,0)+\gamma \chi^{P}+\beta \chi^{V}+\lambda \chi^{P} \chi^{V}+\mu_{i, t}
$$

The difference between the two equations is that in equation (5), the variation of the latent employment surface is assigned to $\mu_{i, t}$. Consequently, the error term is $\mu_{i, t}=\epsilon_{i, t}+l_{i, t}-l(0,0)$. Assigning the variation to the error term is somewhat problematic if $\mu_{i, t}$ is correlated with either of the two indicators $\chi^{P}$ or $\chi^{V}$. Therefore, to obtain unbiased estimates, the following constraints must hold:

$$
\operatorname{Cov}\left(\mu_{i, t}, \chi^{P}\right)=0 \text { and } \operatorname{Cov}\left(\mu_{i, t}, \chi^{V}\right)=0
$$

The top panel of Figure 2 shows that both the venue county group and the control group enjoyed positive employment growth rates. This suggests a positive correlation between $\chi^{P}$ and $\mu_{i, t}$. Furthermore, the bottom panel of Figure 2 shows a substantial difference in the employment levels between the venue county group and the control group. This observation leads to the suggestion that a positive correlation between $\chi^{V}$ and $\mu_{i, t}$ exists. Obviously, and as pointed out by DACHIS, DURANTON, \& TURNER (2010, p. 12), correlations between the two indicator variables $\left(\chi^{P}, \chi^{V}\right)$ and the error term could bias estimates of $\beta_{1}, \beta_{2}$ and, especially 
importantly, $\lambda$. To address this problem, county-fixed effects as well as time-fixed effects were included in equation (3).

$$
e_{i, t}=\delta_{i}+\sum_{t} \beta_{t} \theta_{t}+\lambda \chi^{P} \chi^{V}+u_{i, t}
$$

where $\delta_{i}$ denotes a dummy variable for each single regional unit, that is, countyfixed effects, while the $\theta_{t}$ are defined as a set of dummy variables for each month from January 1990 to December 2008, that is, time-fixed effects. DACHIS, DURANTON, \& TURNER (2010, p. 12) explain by means of the Taylor-series expansion of $l$ the way in which the specification of equation (4) helps to resolve problems caused by unobserved variation in the employment surface.

$$
l_{i t}=l(0,0)+\frac{\partial l}{\partial i} i_{t}+\frac{\partial l}{\partial t} t+\frac{1}{2} \frac{\partial^{2} l}{\partial i^{2}} i_{t}^{2}+\frac{1}{2} \frac{\partial^{2} l}{\partial t^{2}} t^{2}+\frac{\partial^{2} l}{\partial i \partial t} i_{t} t+O(3)
$$

In equation (4), the county-fixed effects $\left(\delta_{i}\right)$ capture non-parametrically the proportion of variation in the employment surface $l$ that is solely attributable to region $i$. Therefore,

$$
\delta_{i}=\sum_{k} \frac{1}{k !} \frac{\partial^{k} l}{\partial i} i_{t}^{k}
$$

where $k$ is the order of the Taylor-series expansion. Analogously, the time-fixed effect $\left(\sum_{t} \theta_{t}\right)$ controls non-parametrically for all variation that depends solely on time $t$; therefore,

$$
\delta_{i}=\sum_{k} \frac{1}{k !} \frac{\partial^{k} l}{\partial t} t^{k}
$$

In equation (4), the error term $u_{i, t}$, consists purely of noise and terms involving both $i$ and $t$, or, formally, $u_{i, t}=\frac{\partial^{2} l}{\partial i \partial t} i_{t} t+O(3)_{-i, t}+v_{i, t}$. Here, $O(3)_{-i, t}$ denotes third- and higher-order terms of the Taylor-series expansion that involve both $i$ and $t$.

Even in the case that county-fixed effects and time-fixed effects capture all variation that is purely attributable to temporal and spatial variation, estimates of equation (4) can be biased. In particular, if different employment trends for the venue counties and non-venue counties exist, confounded estimates of the impact of the Olympic Games might occur if these trends are correlated with the indica- 
tor variables. To obtain unbiased estimates of $\lambda$ using equation (4), the following constraint must hold:

$$
\operatorname{Cov}\left(u_{i, t}, \chi^{P} \chi^{V}\right)=0
$$

A glance at the middle panel of Figure 1 suggests, in fact, that condition (8) does not hold for the data used. It is obvious that the two groups show different developments in the employment figures for the period from 1990 to 2001 . Additionally, from at least the beginning of 2001 to the end of the observation period, employment figures converged strongly. To resolve this problem, several ways of modeling the inherent trends were included in the empirical analysis. First, different linear trends for both groups were considered. Second, to accommodate the fact that the employment figures switch from divergence to convergence within the observation period, two different linear spline trends are included, for which the knotting point is chosen in the absolute maximum of the difference-in-mean curve (March 2001). Third, a non-parametric smoothed trend represented by a locally weighted regression (lowess) is calculated for both groups and then used as a variable in the empirical model. Accordingly, the augmented estimation equation, which includes group-specific trends, can be written as

$$
e_{i, t}=\delta_{i}+\sum_{t} \beta_{t} \theta_{t}+\alpha_{1} \tau^{V}+\alpha_{2}\left(\tau^{V}-\sigma\right)+\lambda \chi^{P} \chi^{V}+v_{i, t},
$$

Here, $\tau^{V}$ is a trend for the treatment group, which consists of the Olympic venue counties, and $\sigma$ is the month of the Olympic Games, July 1996. This second trend term indicates a so-called linear spline trend. Here, the turning point in employment figures is represented by a spline knot, which joins the two differentlysloped trend lines in July 1996 (MARSH \& CORMIER, 2001, p. 2).

\subsection{Identifying the Treatment}

A problem common to all empirical analysis of a treatment -whether it is DD or RDD - is the exact definition of this treatment with respect to several inherent dimensions. The analyzed intervention is rarely completely exogenous and clearly distinct for those dimensions. In the case of the 1996 Olympic Games, the treatment must be defined in three dimensions: time, space, and magnitude. 
Regarding the time dimension, the start of the treatment effect might be gradual because the intended measures were conducted step-by-step, or it might be preceded by a kind of anticipation effect. Analogously, the amplitude as well as the duration of the effect might not be derived from theoretical considerations. Second, from a spatial point of view, the treatment might generate spillover effects to adjacent geographic units. Therefore, an empirical identification strategy must be found that considers these facts. With respect to the time dimension of the treatment, the intervention function can be modeled in several ways. ${ }^{8}$ First, the intervention can be the result of a pure jump; that is, a level shift occurs within the treatment group immediately after the event. In this case, the estimation equation will be equation (4) or equation (9). This specification requires a lasting impact of the Olympic Games on employment.

Second, because such a sustainable effect is not supported by the empirical sports economics literature, the treatment effect should also be modeled as an impulse function; that is, it is assumed that the effect is only active during the staging of the Olympics:

$$
\chi^{P}= \begin{cases}1 & \text { if } t=1996 M 7 \\ 0 & \text { else }\end{cases}
$$

Third and finally, the intervention should be modeled as being more flexible to capture adjustment effects and/or anticipation effects (AHLFELDT, 2010). Therefore, the treatment effect can be identified non-parametrically for a period starting with the announcement of the host of the 1996 Olympic Games.

$$
e_{i, t}=\delta_{i}+\sum_{t} \beta_{t} \theta_{t}+\alpha_{1} \tau^{V}+\alpha_{2} \tau^{N}+\sum_{t=1990 M 9}^{2008 M 12} \lambda_{t} \theta_{t} \chi^{V}+v_{i, t}
$$

Here, 12 separate time dummies are interacted with the respective treatment group dummy. This specification allows the treatment effect to vary freely over time.

Concerning the space dimension, one has to define which geographical units should be regarded as members of the treatment group. HOTCHKISS, MOORE, \&

8 See, e.g., ENDERS (1995, p. 273) for different intervention functions. 
ZOBAY (2003) define their treatment group ("venue and near venue counties" or "VNV") as counties in which Olympic venues were located ("venue counties") plus counties adjacent to these venue counties ("near venue counties"). This seems to be a very broad definition, and, as FEDDERSEN \& MAENNIG (2009) show, their positive and significant level shift is mainly driven by the so-called near venue counties. To avoid such problems, a narrower definition of the treatment group is chosen. At most, the treatment group is expanded to all counties within Georgia that hosted at least one Olympic sporting event; that is, $v$ is composed of the elements $(51,59,63,67,89,121,135,139,215,247)$.

Tab. 2 Frequencies of Olympic Sporting Events in Venue Counties

\begin{tabular}{lrrrr}
\hline \hline County & FIPS & Overall Capacity & $\begin{array}{c}\text { Number of Tick- } \\
\text { eted Sessions }\end{array}$ & $\begin{array}{c}\% \text { of Over- } \\
\text { all Capacity }\end{array}$ \\
\hline Fulton, GA & 121 & $11,273,100$ & 411 & $78.7 \%$ \\
\hline Clayton, GA & 63 & 105,600 & 11 & $0.7 \%$ \\
\hline Rockdale, GA & 247 & 480,000 & 15 & $3.4 \%$ \\
\hline Muscogee, GA & 215 & 140,800 & 16 & $1.0 \%$ \\
\hline Hall, GA & 139 & 276,800 & 16 & $1.9 \%$ \\
\hline Clark, GA & 59 & $1,537,600$ & 32 & $10.7 \%$ \\
\hline DeKalb, GA & 89 & 72,000 & 12 & $0.5 \%$ \\
\hline Gwinnett, GA & 135 & 440,000 & 16 & $3.1 \%$ \\
\hline SUM & & $14,325,900$ & 529 & $100.0 \%$ \\
\hline
\end{tabular}

Notes: Overall capacity is calculated by multiplying stadium capacity by the number of ticket sessions. Calculations based on ATLANTA COMMITTEE FOR THE OLYMPIC GAMES (1997, pp. 539-544).

According to Table 2, almost $80 \%$ of the capacity-weighted Olympic events took place in the City of Atlanta ("Fulton County"), followed by Clark County with about $11 \%$. The other counties each hosted between $0.5 \%$ and $3.5 \%$ of the capacity-weighted events. From a theoretical viewpoint, the economic impacts of sports events are mostly driven by the additional spending of non-resident spectators one would thus expect that counties hosting more Olympic events will benefit the most.

To test whether the effect depends on the number of Olympic events hosted, the empirical strategy will be trimmed to consider differences in the magnitude of the effect for the different venue counties. We thus set the magnitude of the 
Olympic treatment dummy equal to a county's percentage share of the overall spectator capacity. Consequently, the indicator variable $\chi^{V}$ is modified as follows:

$$
\chi^{V}=\left\{\begin{array}{l}
\omega_{i} \text { if } i \in v \\
0 \text { else }
\end{array}\right.
$$

Here, $\omega_{i}$ is equal to county i's percentage share of the Olympic session-weighted spectator capacity, as displayed in column (5) of Table 2, and $v$ is defined as before. Furthermore, aside from Olympic events, the Hartsfield-Jackson Atlanta International Airport ${ }^{9}$ might also benefit from additional visitors. As the airport is located only 7 miles south of the city center of Atlanta and is sited mostly in unincorporated areas of Fulton and Clayton counties, the main impact of the airport could also be expected in Fulton County. As neither Figure 3 nor the seasonally adjusted employment sequence of Clayton County (FIPS 63) reveal any indication of an airport impact in Clayton County, the Hartsfield-Jackson Atlanta International Airport was not considered.

Furthermore, at first glance, Figure 5 in the appendix might suggest that Fulton County is the only county that shows a clear employment peak in July 1996, while no clear visual effect of the Olympic Games can be seen for the other venue counties. Analogous to the modification in equation (11), equation (9) should be adjusted to consider a narrow treatment group definition. We thus restrict the treatment group to Fulton County only.

$$
\chi^{V}= \begin{cases}1 & \text { if } i=121 \\ 0 & \text { else }\end{cases}
$$

Employing approximately 56,000 people, the Hartsfield-Jackson Atlanta International Airport is the largest employer in the state of Georgia (CITY OF ATLANTA, 2010). 
Fig. 3 Absolute Employment Difference and Growth Rates for Counties in Georgia and Distance to the Olympic Center
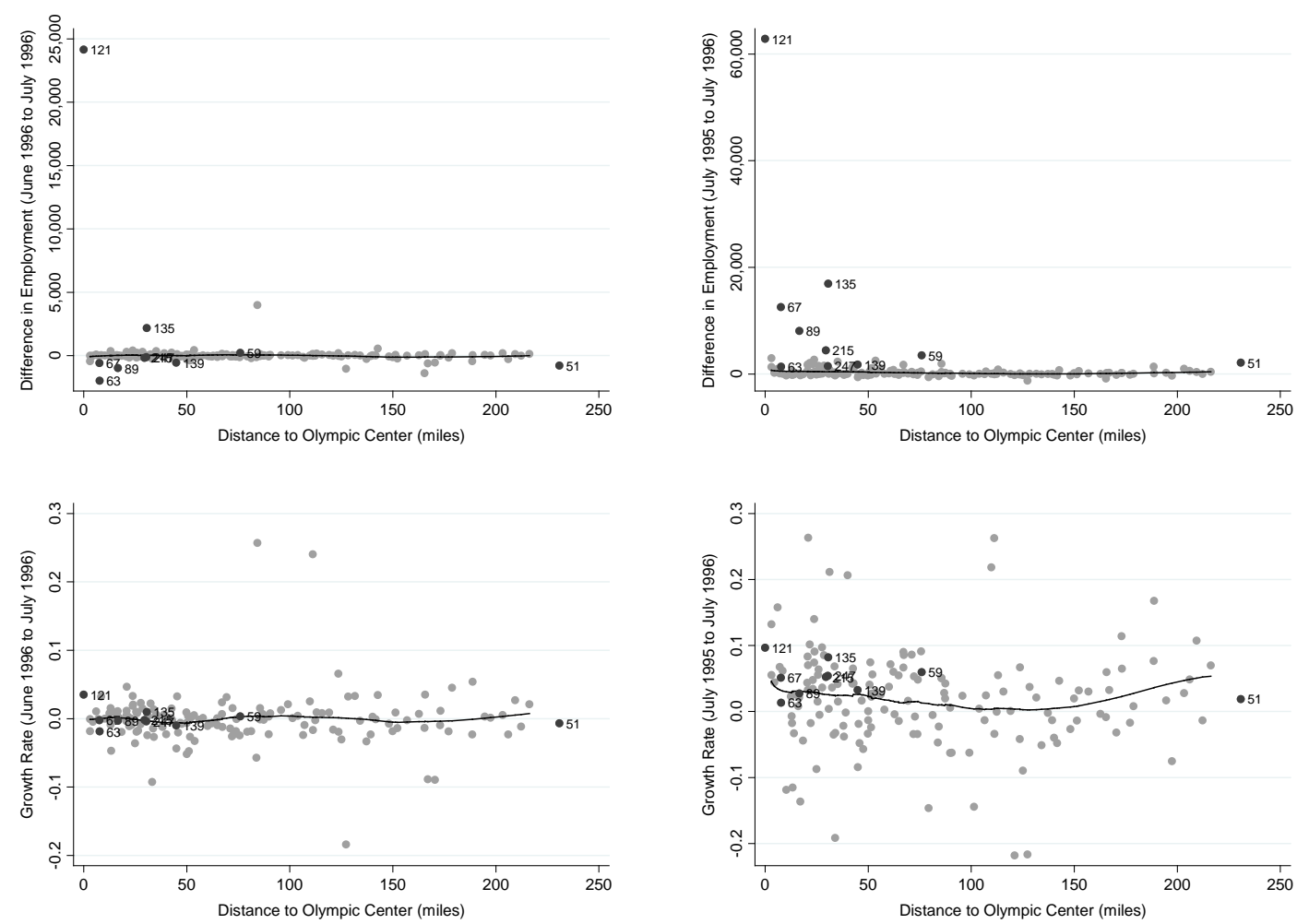

Notes: Employment differences (first row) and growth rates (second row) are based on the change from June 1996 to July 1996 (left column) and from July 1995 to July 1996 (right column). Venue counties are labeled according to their FIPS codes. The solid line is a lowess (smoothed) trend line that is calculated based solely on the non-venue counties.

Last, the treatment might not only be limited to counties hosting Olympic competitions or events. Two main reasons why conjunct areas might also gain from the mega-event are discussed in the sports economics and regional economics literature: (1) avoiding strategies, such as tourists' staying in hotels in the surrounding areas to avoid the overcrowded and potentially expensive Olympic venue regions; (2) spillover effects, that is, the positive effects originally occurring in the main venue regions also extend into surrounding regions. In this case, the effect occurring in the Olympic core is felt in other regions, diminishing with distance from the origin of the primary impact. Figure 3 depicts the relationship between growth in a county and its distance from the Olympic core. No systematic spillovers can be detected either for absolute employment differences or for employment growth. Further, the story does not change if one looks at one-year differences and growth rates instead of one month. 


\section{Results for Aggregated Employment}

First, the results for the most flexible approach according to equation (11) will be presented. This specification is characterized by interactives of the treatment group and time dummies. The results, illustrated in Figure 4, show indices of the "treatment group"-“time dummy" interactive, that is, the relative performance of the treatment group in a given month as revealed by the regression coefficients $\lambda_{t}$. Additionally, the corresponding 90\% confidence intervals are presented as well as a linear and a smoothed lowess trend. The results depicted in panel [a] refer to Fulton County as the only treatment county. Panel [b] corresponds to a treatment group definition according to the percentage of session-weighted capacity, whereas panel [c] is based on the overall treatment group made up of all nine venue counties within Georgia.

One of the aims of this approach is to allow for different effects during the observation period. The period starting with the announcement of Atlanta being chosen as the host of the 1996 Olympics in September 1990 and ending with the opening of the Games in July 1996 is especially interesting. During this period, potential anticipation and adjustment processes could occur. The findings are disappointing for "boosters" as they would predict that due to spending on infrastructure, employment should increase during this preparation phase. Instead, it seems as though the development of employment in Fulton County was less favorable than in the non-treatment group. Until the beginning of 1995, even a negative trend is observable in the effect series. From that date on, a positive trend is obvious, but it has to be mentioned that the performance is still negative relative to the control group. In July 1996, a peak can be observed, revealing a strong employment increase, while the relative performance in August 1996 had already turned into (small) negative figures. Until 2001, the positive local trend beginning in 1995 remains positive, whereas the coefficients remain negative for most of this period. It should also be mentioned that the $\lambda_{t}$ 's are significant for most months in the run-up to the Olympic Games, while - with a few exceptions - they become insignificant in the aftermath. 
The results for the weighted treatment group definition as depicted in panel [b] are quite similar to those of the top panel of Figure 5. The employment peak at the time of the Olympic Games is evident again. The effect series now show positive coefficients in the aftermath of the Games until the end of 2000, but the coefficients are insignificant for most months during this period.

Finally, the results for the treatment group including all venue counties on an unweighted basis disclose no obvious Olympic effect. As there is no visible peak during the Olympics for this treatment definition, one can conclude, bearing in mind the results for the other two treatment definitions, that the observed employment gain in July 1996 only occurs in Fulton County and maybe - to some extent - in Clark County. ${ }^{10}$

${ }^{10}$ This hypothesis might also be weakly confirmed by the sequence of seasonally adjusted employment for Clark County displayed in Figure 5 in the appendix. 
Fig. 4 Monthly Treatment Effects

[a]

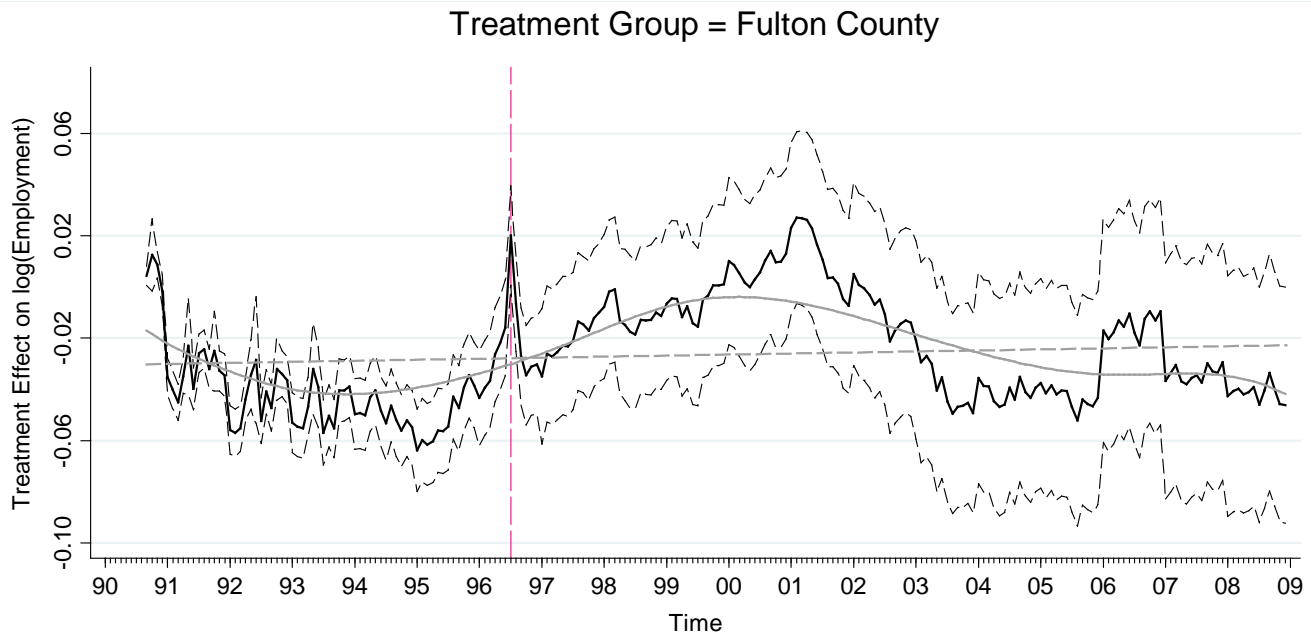

Treatment Group $=$ Venue Counties (Percentage of Session Weighted Capacity)

[b]

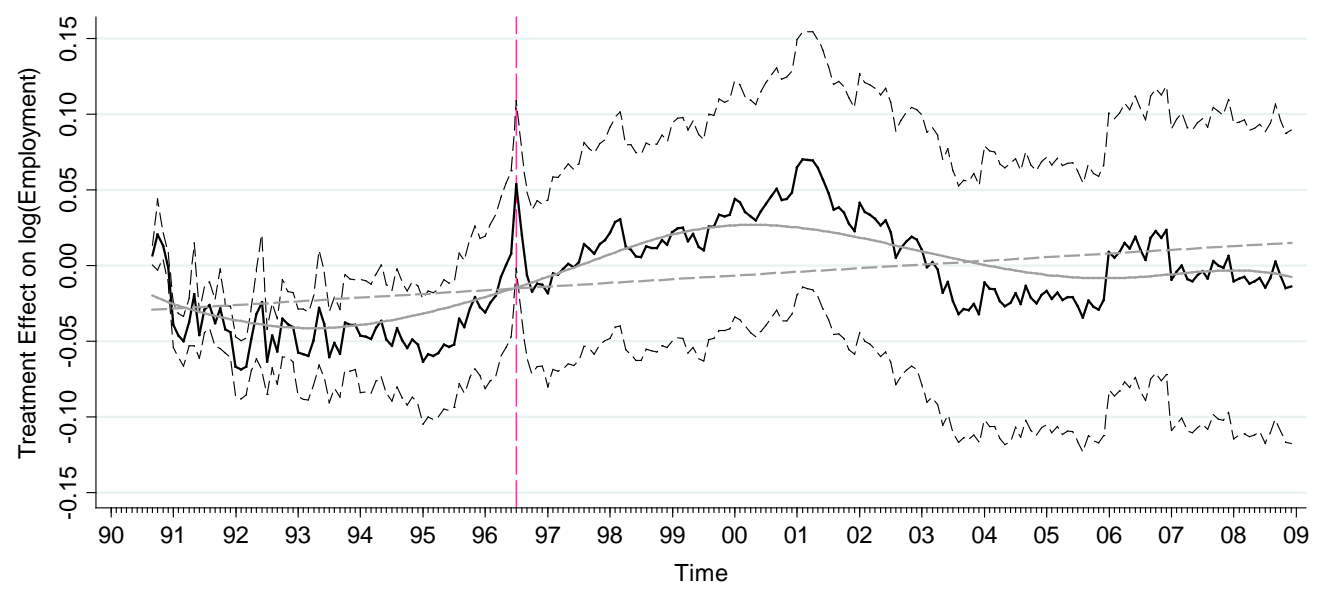

Treatment Group $=$ Venue Counties $($ Unweighted $)$

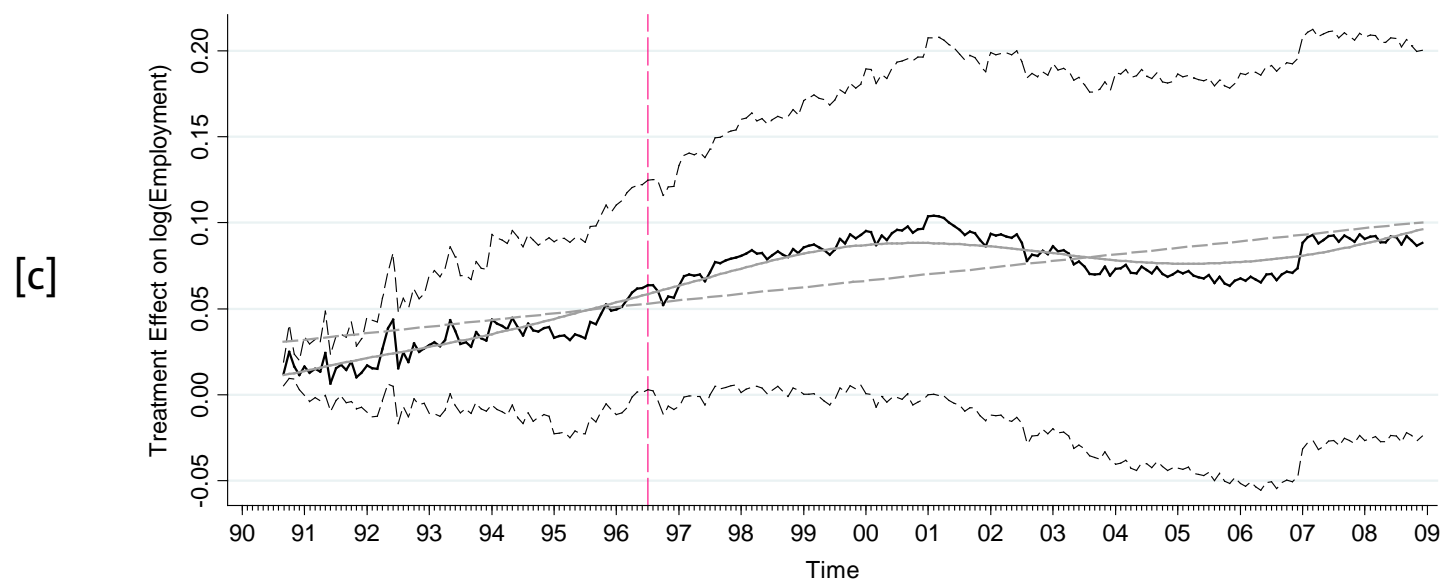

\begin{tabular}{|ll|}
\hline Treatment Index & $-----90 \%$ Conf. Interval \\
\hline Lowess Trend & ----- Linear Trend \\
\hline
\end{tabular}

Notes: Treatment index is constructed of the interaction between monthly fixed effects and the treatment group dummy. 
So far, these results indicate evidence of a very narrow Olympic effect that is extremely concentrated in the time dimension as well as in the spatial dimension. In the next step, we turn back to a more traditional DD setup. A dummy variable testing for a persistent level shift caused by the Olympic Games was included. We abstain from including an additional dummy variable capturing a potential adjustment process in the pre-Olympics era as no indication of the existence of such a process could be found previously.

Table 3 contains the results for different regressions based on equation (12). The first three columns belong to the treatment group "Fulton County", the next three columns belong to the "session capacity weighted" treatment group according to equation (15), and the last three columns refer to the treatment group definition based on the "unweighted venue counties" according to equation (2). For each of these three definitions, the first column is estimated without any trend, while the second (third) columns consider a linear (spline) trend for the treatment group. As shown by BERTRAND, DUFLO, \& MULLAINATHAN (2004), DD models are frequently subject to serial correlation, which might lead to an overestimation of the significance of the "intervention" dummy. To check for such problems, we performed an LM test for serial correlation in a fixed effects model as suggested by BALTAGI (2001, pp. 94-95). ${ }^{11}$ Note that the test clearly rejects the null hypothesis of no serial correlation and that, as a result, the standard errors are corrected using an arbitrary variance-covariance matrix as recommended by BERTRAND, DUFLO, \& MULLAINATHAN (2004) in all estimations. In all nine models, the coefficient of the variable of interest $\chi^{P} \chi^{V}$ is insignificant on all conventional levels; that is, for none of the different treatment group definitions can a persistent level shift in aggregated employment be attested.

Table 4 shows the results of equation (12) subject to definition (13). The structure of the table is the same as described before. These results confirm the insights generated by the flexible approach based on equation (14). If the treatment group is defined according to the definition "unweighted venue counties", no

${ }^{11}$ The LM test statistic is $L M_{5}=\sqrt{N T^{2} /(T-1)\left(\tilde{v}^{\prime} \tilde{v}_{-1} / \tilde{v}^{\prime} \tilde{v}\right)}$, which is asymptotically distributed as $N(0,1)$. 
significant impulse can be detected in July 1996. In contrast, regarding the other two treatment group definitions, "session capacity weighted venue counties" and "Fulton County", the coefficients isolating a pure impulse are always significant at the $1 \%$ level. These effects are robust with respect to the inclusion of spatially differentiated trends. The last row of the table displays the Olympic employment increases in percentages. Insignificant coefficients of the variable of interest are denoted by "no", while in the opposite case, the displayed figures are adjusted coefficients.

Based on the econometric analysis of aggregated employment for counties in Georgia, it can be concluded that - according to two different DD variants - a highly localized Olympic effect occurred. In other words, this effect appears only in Fulton County and exclusively during July 1996. Regardless of the short duration of just one month, the effect of about $4.2 \%$, which can be translated into some 29,000 additional jobs in July 1996 , is impressive. 


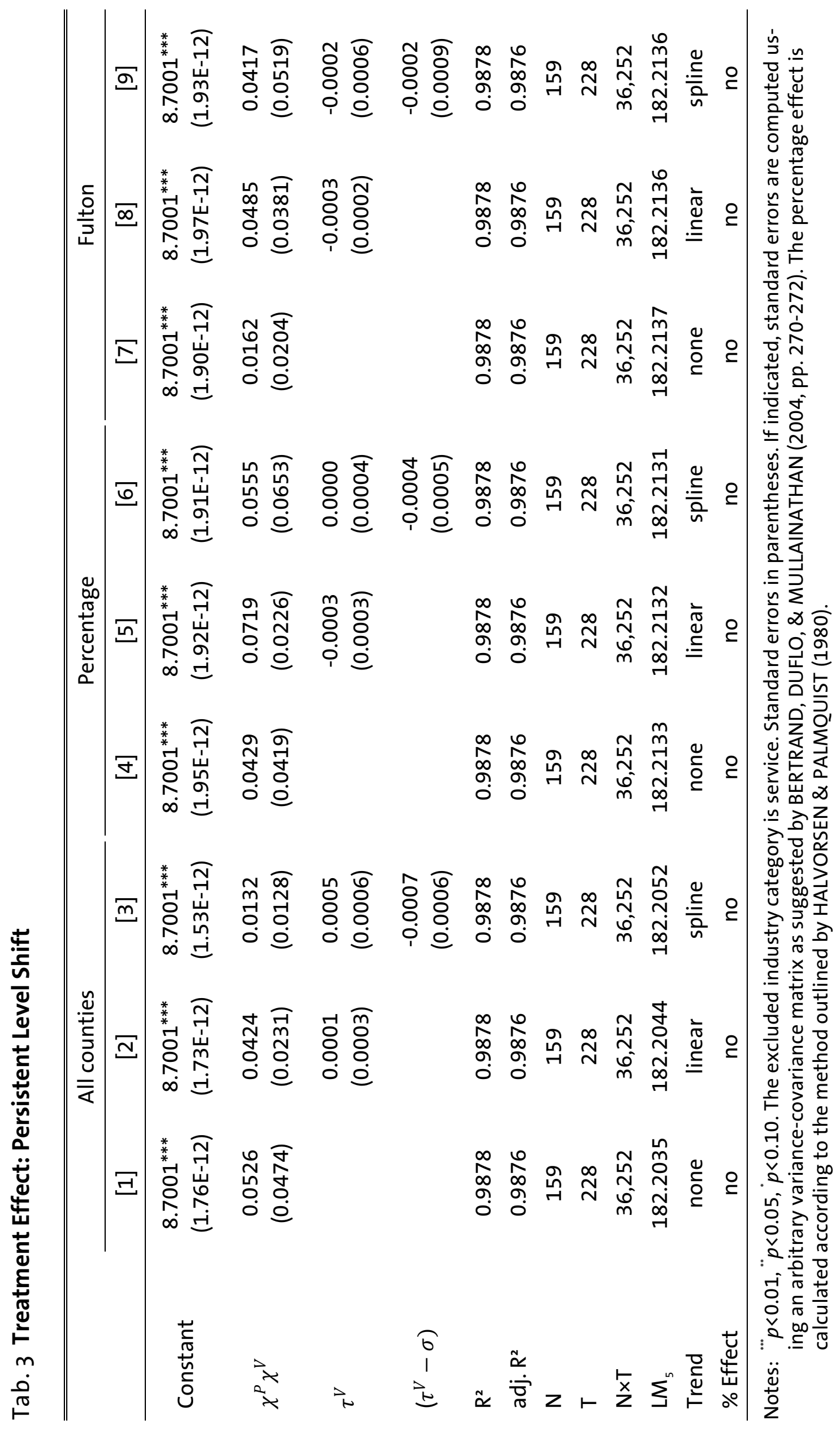




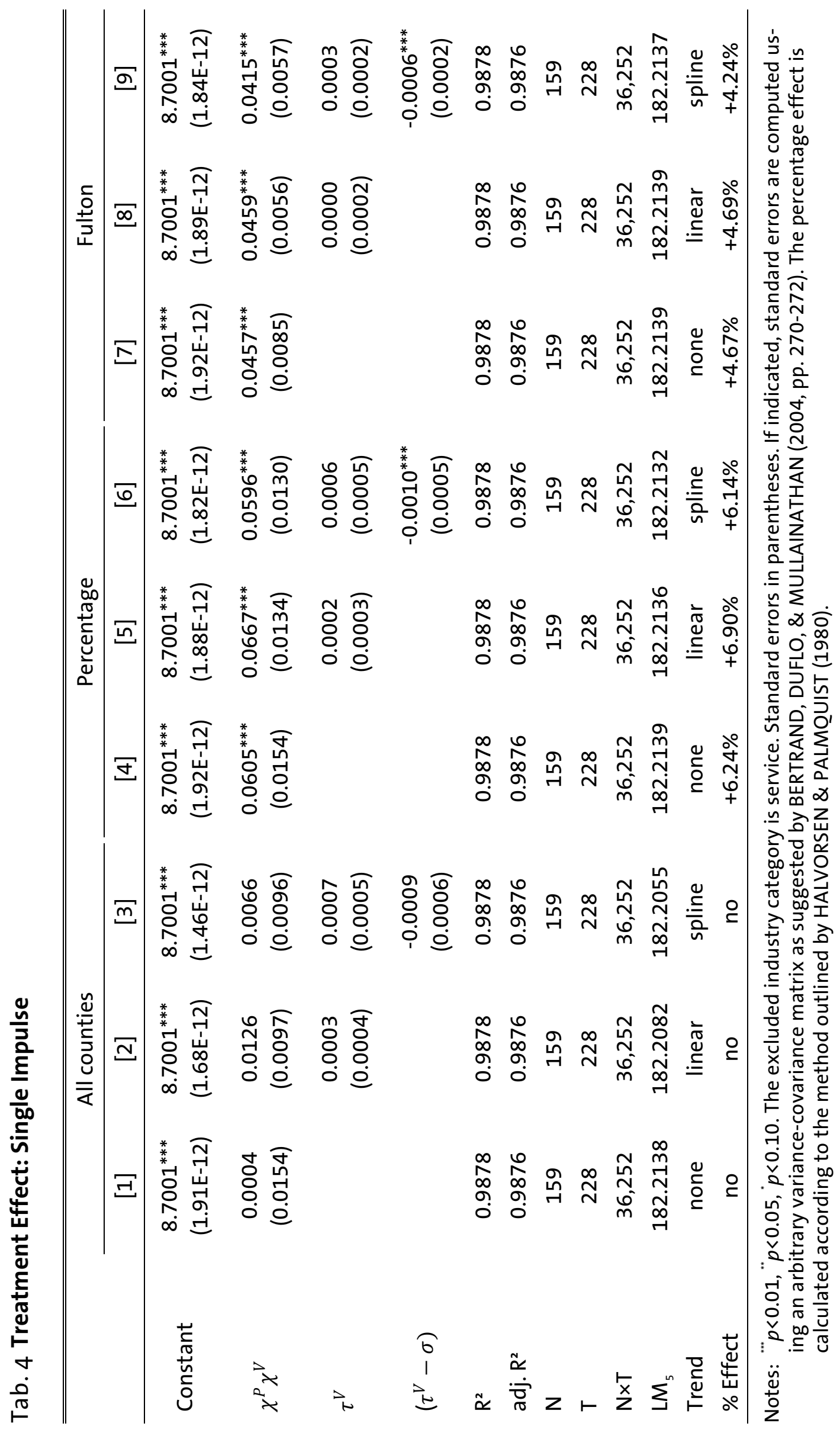




\section{Results of Sectoral Analysis}

As described above, a preferable strategy in identifying an economic impact of a sports mega-event is to reduce the size of the metaphorical haystack. As shown above, the reduction of noise by using monthly county data was already promising. Here, the potential statistical noise should be further reduced by employing sector-specific employment data. Again, the two different variants of the DD approach will be applied.

As this treatment group specification proved to be superior in the empirical analyses of aggregated employment, and to save space, only the Fulton County treatment group definition is displayed. Furthermore, in the case of the more traditional DD regressions, only the impulse intervention is employed. As mentioned above, the availability of county-level data is limited due to the absence of any establishment in this industry or because the data are subject to disclosure restrictions. In addition, some sectors were excluded because (1) Fulton County has no complete employment sequence in this sector and/or (2) the number of available counties exhibiting a complete employment sequence is too small. Finally, 12 two-digit and four three-digit NAICS sectors could be included in the analysis. It is important to mention that this leads to different compositions of the control group among the different sector-specific regressions. As a result, the sizes of significant Olympic effects cannot be compared without caution. Finally, when interpreting Figures 5 and 6 , one has to consider that the scale of the ordinate axis differs between the panels.

Figures 5 and 6 depict a negative trend in the relative employment development between Fulton County and the remaining counties of Georgia in nine of $12 \mathrm{sec}-$ tors. Manufacturing, real estate, and entertainment enjoy positive relative development in Fulton County. Regarding the Olympic effect, hardly any evidence for a persistent shift in the aftermath or an adjustment process in the preparation is supported by the flexible DD regressions. Nevertheless, short-term effects can be found in the sectors "retail trade", "accommodation and food services", and "arts, entertainment, and recreation". To some extent, it is surprising that there is no visible Olympic impact for the construction industry as "booster" often predict 
large employment gains in this industry due to the construction work in the runup to the event.

The non-effect might be due to a relatively low infrastructure investment budget for Atlanta of some US\$609 million, ${ }^{12}$ which the Corporation for Olympic Development in Atlanta (CODA) also used for neighborhood developments and pedestrian improvements (FRENCH \& DISHER, 1997, p. 385). These limited investments stand in contrast to cases such as the 1992 Barcelona Olympic Games and the 1988 Seoul Olympic Games, which used the mega-events to drive fundamental urban renovation (MUÑOZ, 1997, p. 6). Even in the case of the FIFA World Cup 2006 in Germany, where $€ 3.8$ billion was spent for stadium construction and related infrastructure, no short-term employment boost during the construction phase could be identified (FEDDERSEN, GRÖTZINGER, \& MAENNIG, 2009).

${ }^{12}$ Cf. UNITED STATES GENERAL ACCOUNTING OFFICE (2000, pp. 5-6) , which also reports investments of some US\$1.3 billion for the 2002 Salt Lake City Olympic Games. 
Fig. 5 Monthly Treatment Effects for Sectors
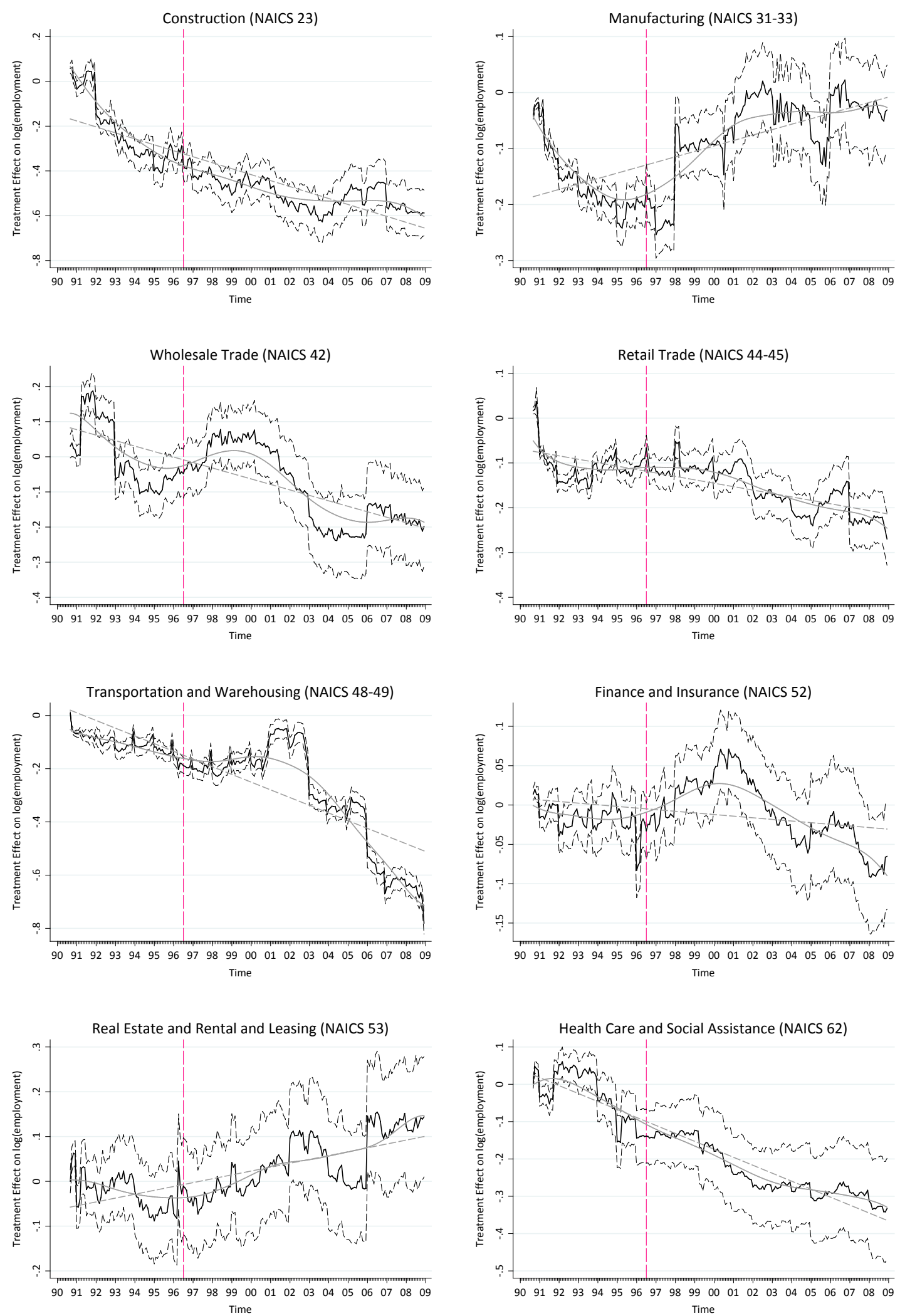

Notes: Treatment index is constructed of the interactions between monthly fixed effects and the treatment group dummy. The treatment group is defined as Fulton County. The vertical line marks the month of the Olympic Games (July 1996). 
Fig. 6 Monthly Treatment Effects for Sectors (cont.)
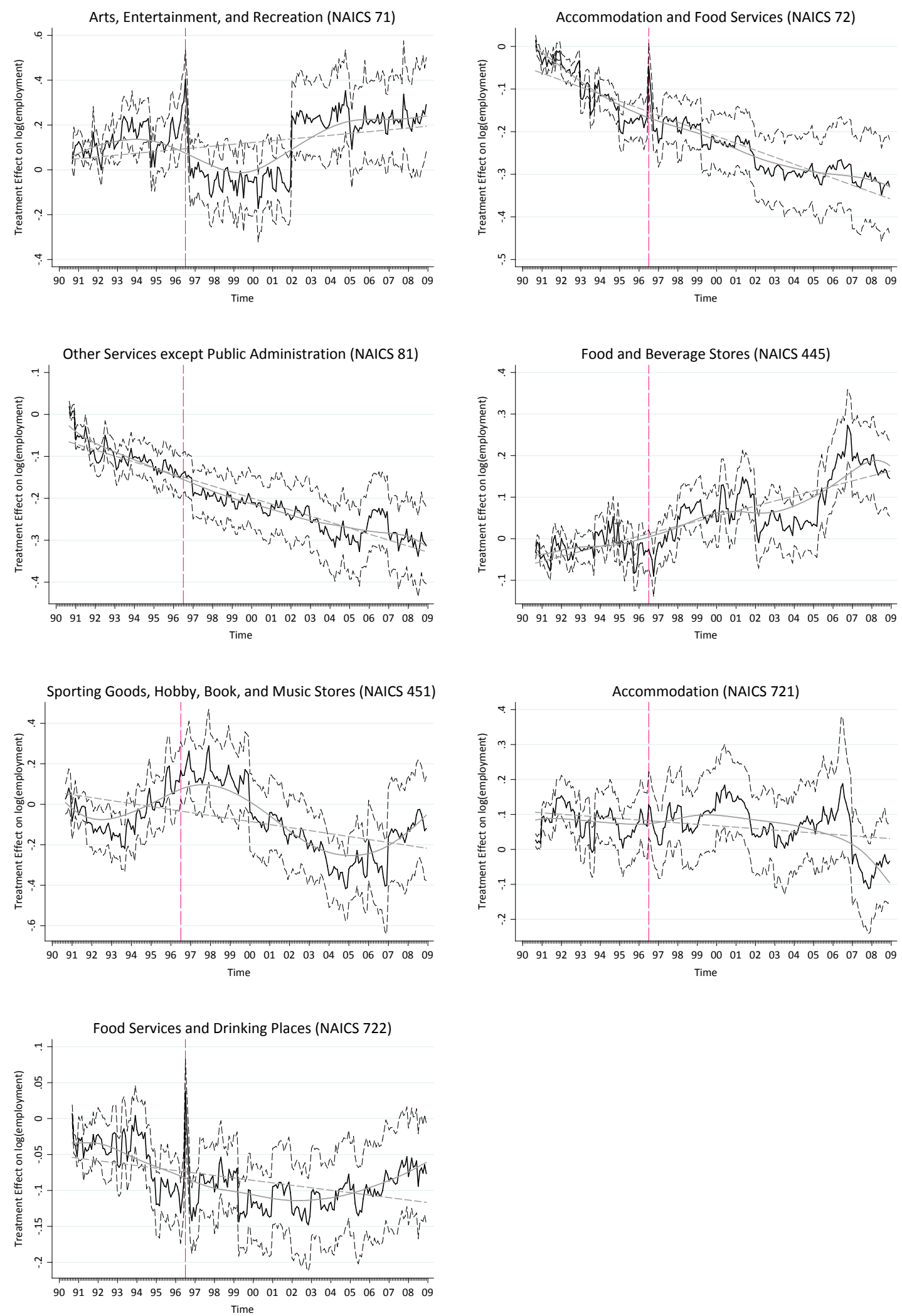

Notes: Treatment index is constructed of the interactions between monthly fixed effects and the treatment group dummy. The treatment group is defined as Fulton County. The vertical line marks the month of the Olympic Games (July 1996). 
The more traditional DD approach of applying a single impulse as an intervention (Tables 5 and 6) does not replicate the positive Olympic impulse found in the aggregated time series for all sectors of Georgia's labor market. Indeed, the Olympic impulse dummy is not significantly different from zero for five of the 12 two-digit sectors. On the level of three-digit subsectors, two sectors are not significantly affected, one is positively affected, and one is negatively affected.

Starting with the two-digit sectors, the coefficient for "manufacturing (NAICS 31$33)$ " is negative and highly significant. It can be translated into a $7.2 \%$ decrease in jobs during the month of the Olympic Games. In contrast, the same sectors as above show a significantly positive Olympic effect. The largest employment effect can be found in the "arts, entertainment, and recreation (NAICS 71)" industry (+33\%), followed by the "accommodation and food services (NAICS 72)" industry (17\%). Also, remarkable job impulses can be estimated for the "retail trade (NAICS 44-45)" sector (+7.5\%), the "other services (NAICS 81)" sector (+5.1\%), and the "transportation and warehousing (NAICS 48-49)" sector (+4.9\%). Other industries, such as "health care (NAICS 62)" and "real estate (NAICS 53)", appear to show no significant effect.

The analysis on the three-digit level of sectors clarifies that the employment effect in the sector "accommodation and food services (NAICS 72)" is driven by the subsector "food services and drinking places (NAICS 722)", while no significant Olympic effect can be shown for the "accommodation (NAICS 721)" subsector. Within the overall positively affected sector "retail trade (NAICS 44-45)", the subsector "food and beverage stores (NAICS 445)" even realized a decrease in jobs for the duration of the Olympic Games, while another subsector, "sporting goods, hobby, book, and music stores (NAICS 451)", had an increase of $28 \%{ }^{13}$

${ }^{13}$ The result has to be interpreted carefully as for NAICS 451 ("sporting goods, hobby, book, and music stores"), the effective control group is small, with only 23 counties. 
Tab. 5 Treatment Effect on Sectors

\begin{tabular}{|c|c|c|c|c|c|c|c|c|}
\hline Industry & 23 & $31-33$ & 42 & $44-45$ & $48-49$ & 52 & 53 & 62 \\
\hline Constant & $\begin{array}{c}5.964^{* * *} \\
(0.039)\end{array}$ & $\begin{array}{c}7.670^{* * *} \\
(0.030)\end{array}$ & $\begin{array}{c}6.002^{* * *} \\
(0.044)\end{array}$ & $\begin{array}{c}6.560^{* * *} \\
(0.020)\end{array}$ & $\begin{array}{c}3.622^{* * *} \\
(0.020)\end{array}$ & $\begin{array}{c}5.718^{* * *} \\
(0.025)\end{array}$ & $\begin{array}{c}5.246^{* * *} \\
(0.058)\end{array}$ & $\begin{array}{c}7.086^{* * *} \\
(0.046)\end{array}$ \\
\hline$\chi^{P} \chi^{V}$ & $\begin{array}{c}0.025 \\
(0.021)\end{array}$ & $\begin{array}{c}-0.075^{* * *} \\
(0.018)\end{array}$ & $\begin{array}{c}0.010 \\
(0.032)\end{array}$ & $\begin{array}{c}0.072^{* * *} \\
(0.011)\end{array}$ & $\begin{array}{c}0.048^{* * *} \\
(0.006)\end{array}$ & $\begin{array}{l}-0.022 \\
(0.016)\end{array}$ & $\begin{array}{l}-0.031 \\
(0.033)\end{array}$ & $\begin{array}{c}0.025 \\
(0.028)\end{array}$ \\
\hline $\mathrm{R}^{2}$ & 0.955 & 0.955 & 0.969 & 0.982 & 0.987 & 0.974 & 0.959 & 0.984 \\
\hline adj. $R^{2}$ & 0.955 & 0.955 & 0.968 & 0.982 & 0.987 & 0.974 & 0.958 & 0.983 \\
\hline$N \times T$ & 21,656 & 27,132 & 13,679 & 33,513 & 36,252 & 20,976 & 13,452 & 8,892 \\
\hline $\mathrm{LM}_{5}$ & 137.345 & 160.564 & 112.131 & 173.043 & 172.970 & 140.755 & 110.712 & 91.872 \\
\hline$\%$ Effect & No & $-7.20 \%$ & no & $+7.52 \%$ & $+4.91 \%$ & no & no & no \\
\hline tes: “ $p$ & $\therefore P$ & $p>0$. & . Robust & that & rors, wh & are co & puted $\mathrm{u}$ & $\begin{array}{l}g \text { an } a r l \\
\text { IINATH }\end{array}$ \\
\hline
\end{tabular}

Tab. 6 Treatment Effect on Sectors (cont.)

\begin{tabular}{lccccccc}
\hline \hline Industry & 71 & 72 & 81 & 445 & 451 & 721 & 722 \\
\hline Constant & $5.888^{* * *}$ & $7.575^{* * *}$ & $5.456^{* * *}$ & $5.856^{* * *}$ & $5.233^{* * *}$ & $6.326^{* * *}$ & $6.464^{* * *}$ \\
& $(0.065)$ & $(0.033)$ & $(0.034)$ & $(0.031)$ & $(0.098)$ & $(0.043)$ & $(0.029)$ \\
$\chi^{P} \chi^{V}$ & $0.288^{* * *}$ & $0.154^{* * *}$ & $0.050^{* *}$ & $-0.076^{* * *}$ & $0.247^{* * *}$ & 0.062 & 0.121 \\
$\mathrm{R}^{2}$ & $(0.047)$ & $(0.016)$ & $(0.021)$ & $(0.020)$ & $(0.048)$ & $(0.043)$ & $(0.016)$ \\
adj. $\mathrm{R}^{2}$ & 0.937 & 0.978 & 0.972 & 0.952 & 0.939 & 0.968 & 0.984 \\
$\mathrm{~N} \times \mathrm{T}$ & 7,296 & 9,576 & 20,520 & 20,748 & 5,472 & 6,156 & 16,872 \\
$\mathrm{LM}_{5}$ & 77.710 & 94.832 & 136.548 & 138.074 & 70.046 & 74.365 & 122.954 \\
$\%$ Effect & $+33.37 \%$ & $+16.62 \%$ & $+5.12 \%$ & $-7.31 \%$ & $+28.00 \%$ & no & $+12.83 \%$ \\
\hline
\end{tabular}

Notes: $" p<0.01, " p<0.05, p<0.10$. Robust standard errors, which are computed using an arbitrary variance-covariance matrix as suggested by BERTRAND, DUFLO, \& MULLAINATHAN (2004, pp. 270-272), are given in parentheses. No trend is considered. The percentage effect is calculated according to the method outlined by HALVORSEN \& PALMOUIST (1980). 


\section{Conclusion}

The 1996 Atlanta Olympic Games are unique because they represent one of the very few large sporting events attested by academic ex post analysis to have created significantly positive employment effects. HOTCHKISS, MOORE, \& ZOBAY (2003) estimated an effect of some additional 324,000 jobs. BAADE \& MATHESON (2002) estimate employment gains that range from insignificant to slightly significant employment effects, in the range of 3,500 to 42,500 additional jobs. This paper differs from these two studies in several respects. First, we use monthly data, which seems to be appropriate due to the short duration of the Olympic Games (16 days). On the basis of a partially non-parametric model as well as a more traditional DD model, we have to reject the hypothesis of a long-term and persistent employment boost caused by the Olympics. A significant employment impulse of some 29,000 jobs can be identified exclusively for the month of the staging of the Olympic Games and exclusively in Fulton County, where most of the Olympic events were held.

In a second innovative step, the data are disaggregated to two-digit and threedigit sector levels. This analysis clarifies that the short-term effect is concentrated in some few sectors, namely, "arts, entertainment, and recreation", "accommodation and food service", and "retail trade". The analysis on the three-digit level of sectors made it evident that the effects found at the sector level might differ among the corresponding subsectors. For example, within the overall positively affected sector "retail trade", the subsector "food and beverage stores" actually realized a decrease in jobs for the duration of the Olympic Games, while another subsector, "sporting goods, hobby, book, and music stores" enjoyed an increase in employment. The $17 \%$ employment gain found for the "accommodation and food service" industry during July 1996 can be translated into some 9,900 additional jobs, while the $33 \%$ jump in the "arts, entertainment, and recreation" industry corresponds to some 3,000 additional employees for the same time period. In the 
same way, the 7.5\% (5.1\%) jump in the "retail trade" ("other services") sector is equivalent to some $4,300(1,000)$ additional jobs. ${ }^{14}$

Coming to the implications for economic policy and public funding, we have to conclude that the absolute increases in employment are small, even in the obviously outstanding case of the 1996 Atlanta Olympic Games. Whereas effects in areas such as feelgood, happiness, and image caused by mega-sporting events might be an argument for public funding, the employment effects seem too small and too concentrated sectorally and locally to justify public funding from general sources at the state level. However, disaggregated analysis such as our study might contribute to identifying potential sources for future funding: Sectors such as "arts, entertainment, and recreation", "accommodation and food service", and "retail trade" might have enough self-interest to cooperate in contributing to funding these mega-events.

The strategy of reducing the size of the haystack by using more disaggregated data as previously used by, for example, BAADE, BAUMANN, \& MATHESON (2008a, 2008b), COATES (2006), or HAGN \& MAENNIG (2009), seems to be promising for the economic analysis of large sporting events and should be extended in further research. Such analysis could also shed more light on the potentially asymmetrical reaction of the American and European labor markets. JASMAND \& MAENNIG (2008) find no employment effects of the 1972 Munich Olympic Games, but they do find significant income effects; these findings may be associated with a reduced local mobility of labor and a more rigid regulation of labor markets (LAYARD, NICKELL, \& JACKMAN, 2005; NICKELL, 1997).

${ }^{14}$ If one compares these figures for the subsectors with the number of additional jobs derived from the analysis of aggregated employment it has to be considered that, the control group compositions differ between the regressions. Furthermore, the "public administration" sector was excluded from the sectorally disaggregated analysis but not from the aggregated one. 


\section{Appendix}

Tab. 7 Venues of the 1996 Olympic Games

\begin{tabular}{|c|c|c|c|c|c|c|}
\hline Venue & County & FIPS & Capacity & Events/Sports & $\begin{array}{l}\text { Sessions } \\
\text { (Number) }\end{array}$ & $\begin{array}{l}\text { Sessions } \\
\text { (Days) }\end{array}$ \\
\hline $\begin{array}{l}\text { Alexander Memorial } \\
\text { Coliseum }\end{array}$ & Fulton, GA & 13121 & 10,000 & Boxing & 26 & 15 \\
\hline Atlanta Beach & Clayton, GA & 13063 & 9,600 & Beach Volleyball & 11 & 6 \\
\hline $\begin{array}{l}\text { Atlanta-Fulton Coun- } \\
\text { ty Stadium }\end{array}$ & Fulton, GA & 13121 & 54,000 & Baseball & 32 & 12 \\
\hline $\begin{array}{l}\text { Clark Atlanta Univer- } \\
\text { sity Stadium }\end{array}$ & Fulton, GA & 13121 & 5,000 & Field Hockey & 14 & 11 \\
\hline Florida Citrus Bowl & Orange, FL & 12095 & 65,000 & Soccer & 6 & 6 \\
\hline Georgia Dome & Fulton, GA & 13121 & 79,000 & $\begin{array}{l}\text { Gymnastics, Basketball, } \\
\text { Handball }\end{array}$ & 64 & 16 \\
\hline $\begin{array}{l}\text { Georgia International } \\
\text { Horse Park }\end{array}$ & Rockdale, GA & 13247 & 32,000 & $\begin{array}{l}\text { Equestrian, Mountain Bike } \\
\text { Racing, Modern Pentath- } \\
\text { lon }\end{array}$ & 15 & 14 \\
\hline $\begin{array}{l}\text { Georgia State Univer- } \\
\text { sity Gymnasium }\end{array}$ & Fulton, GA & 13121 & 3,500 & Badminton & 22 & 9 \\
\hline $\begin{array}{l}\text { Georgia Tech Aquatic } \\
\text { Center }\end{array}$ & Fulton, GA & 13121 & 15,000 & $\begin{array}{l}\text { Diving, Swimming, Water } \\
\text { Polo }\end{array}$ & 53 & 14 \\
\hline $\begin{array}{l}\text { Georgia World Con- } \\
\text { gress Center }\end{array}$ & Fulton, GA & 13121 & 7,300 & $\begin{array}{l}\text { Fencing, Handball, Judo, } \\
\text { Table Tennis, Weight- } \\
\text { lifting, Wrestling }\end{array}$ & 111 & 15 \\
\hline Golden Park & Muscogee, GA & 13215 & 8,800 & Softball & 16 & 9 \\
\hline Lake Lanier & Hall, GA & 13139 & 17,300 & $\begin{array}{l}\text { Canoe/Kayak Race, } \\
\text { Rowing }\end{array}$ & 16 & 14 \\
\hline Legion Field & Jefferson, $A L$ & 01073 & 81,700 & Soccer & 8 & 8 \\
\hline Road Courses & Fulton, GA & 13121 & $\mathrm{n} / \mathrm{a}$ & Athletics, Road Cycling & $\mathrm{n} / \mathrm{a}$ & $n / a$ \\
\hline $\begin{array}{l}\text { Morehouse College } \\
\text { Gymnasium }\end{array}$ & Fulton, GA & 13121 & 6,000 & Basketball & 13 & 9 \\
\hline $\begin{array}{l}\text { Morris Brown College } \\
\text { Stadium }\end{array}$ & Fulton, GA & 13121 & 15,000 & Field Hockey & 18 & 14 \\
\hline $\begin{array}{l}\text { Ocoee Whitewater } \\
\text { Center }\end{array}$ & Polk, TN & 47139 & 14,400 & Canoe/Kayak Slalom & 12 & 3 \\
\hline Olympic Stadium & Fulton, GA & 13121 & 85,600 & $\begin{array}{l}\text { Athletics, Opening and } \\
\text { Closing Ceremonies }\end{array}$ & 18 & 10 \\
\hline Omni Coliseum & Fulton, GA & 13121 & 16,500 & Volleyball & 32 & 16 \\
\hline Orange Bowl & $\begin{array}{l}\text { Miami-Dade, } \\
\text { FL }\end{array}$ & 12086 & 72,700 & Soccer & 8 & 8 \\
\hline $\begin{array}{l}\text { RFK Memorial Sta- } \\
\text { dium }\end{array}$ & $\begin{array}{l}\text { District of } \\
\text { Columbia }\end{array}$ & 11001 & 56,500 & Soccer & 6 & 6 \\
\hline Sanford Stadium & Clark, GA & 13059 & 86,100 & Soccer & 16 & 10 \\
\hline $\begin{array}{l}\text { Stone Mountain Park } \\
\text { Velodrome }\end{array}$ & DeKalb, GA & 13089 & 6,000 & Archery, Track Cycling & 12 & 12 \\
\hline $\begin{array}{l}\text { Stone Mountain Park } \\
\text { Tennis Center }\end{array}$ & Gwinnett, GA & 13135 & 27,500 & Tennis & 16 & 14 \\
\hline $\begin{array}{l}\text { University of Georgia } \\
\text { Coliseum }\end{array}$ & Clark, GA & 13059 & 10,000 & $\begin{array}{l}\text { Rhythmic Gymnastics, } \\
\text { Volleyball }\end{array}$ & 16 & 14 \\
\hline Wassaw Sound & Chatham, GA & 13051 & $\mathrm{n} / \mathrm{a}$ & Yachting & 24 & 12 \\
\hline $\begin{array}{l}\text { Wolf Creek Shooting } \\
\text { Center }\end{array}$ & Fulton, GA & 13121 & 7,500 & Shooting & 8 & 8 \\
\hline
\end{tabular}

Source: ATLANTA COMMITTEE FOR THE OLYMPIC GAMES (1997, pp. 539-544). 


\section{Fig. 7 Seasonally Adjusted Employment in Venue Counties (All Industries)}
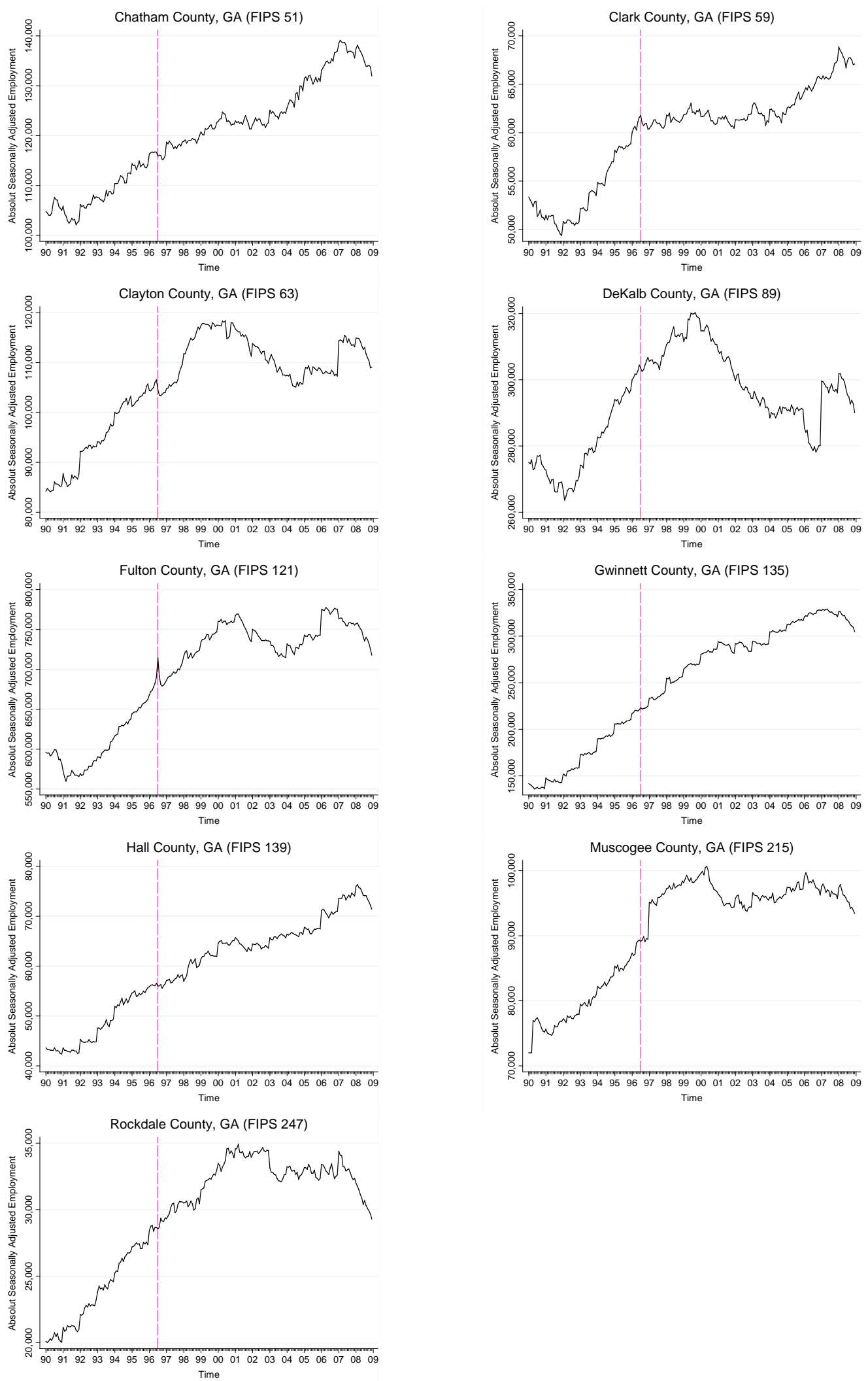

Notes: Calculations based on BUREAU OF LABOR STATISTICS (2009). The vertical dashed line marks the month of the Olympic Games (July 1996). The scale of the ordinate is not normalized. 
Fig. 8 Different Trends for Treatment and Control Group

[a]

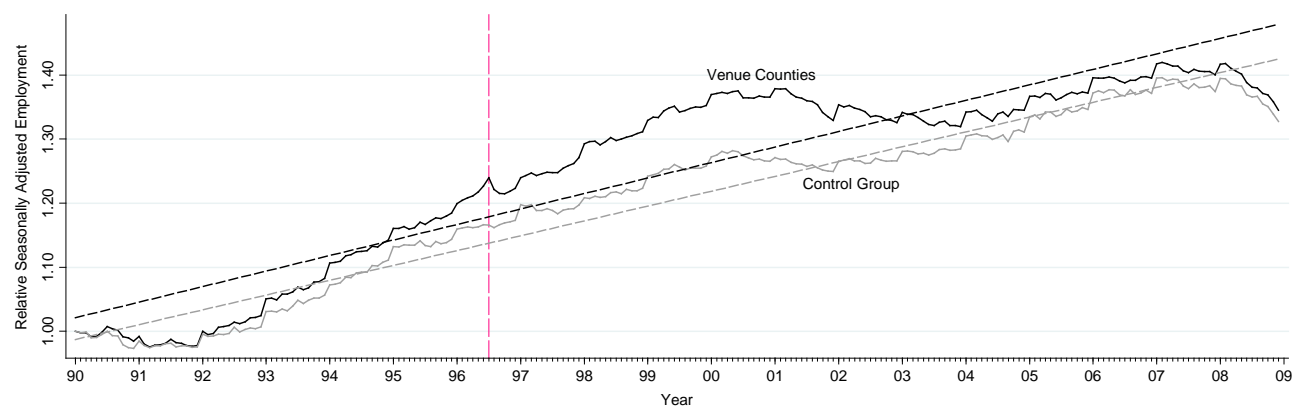

[b]

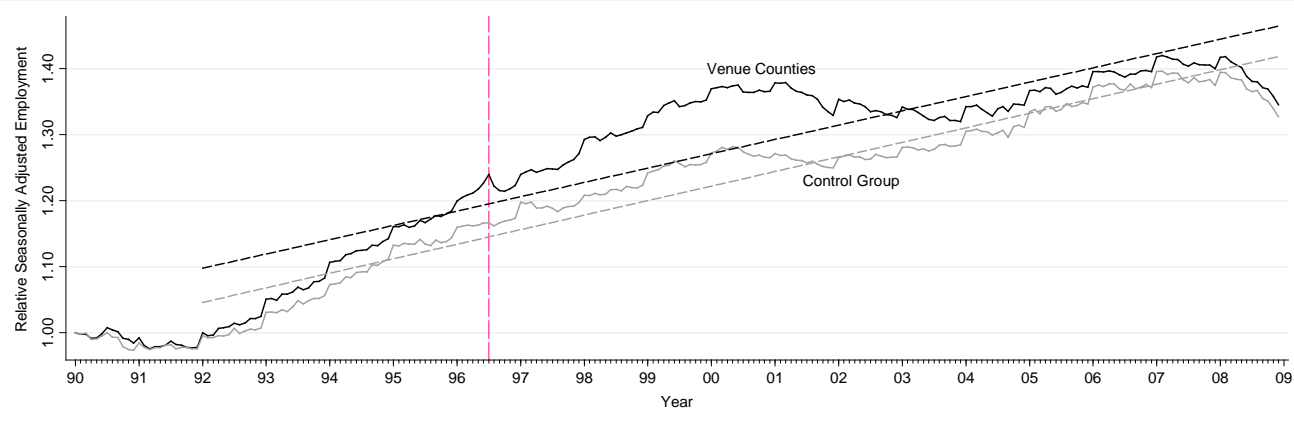

[c]

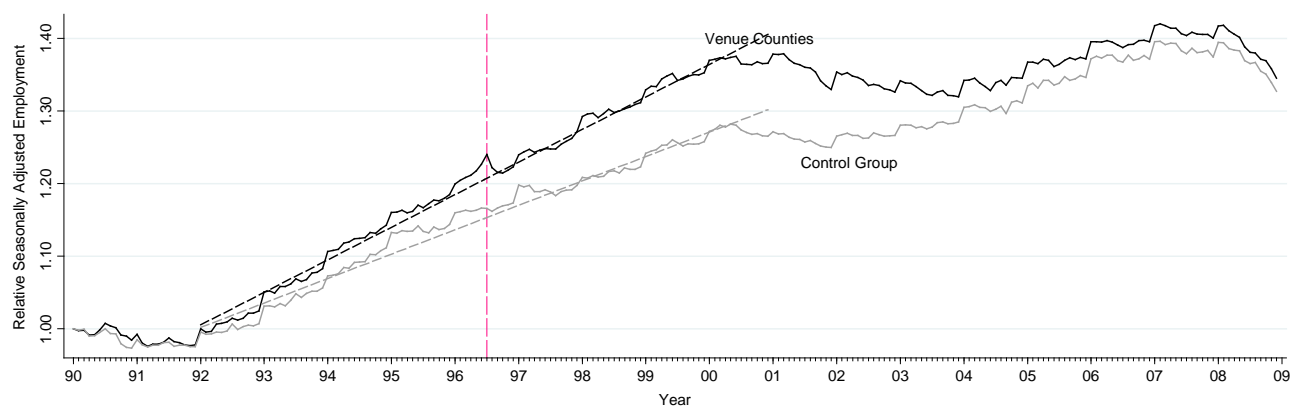

[d]

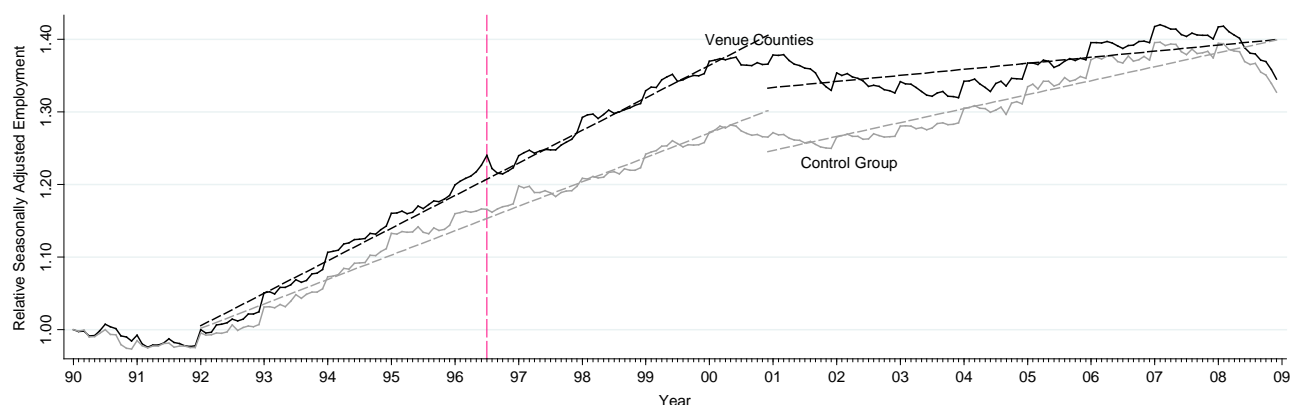

[e]

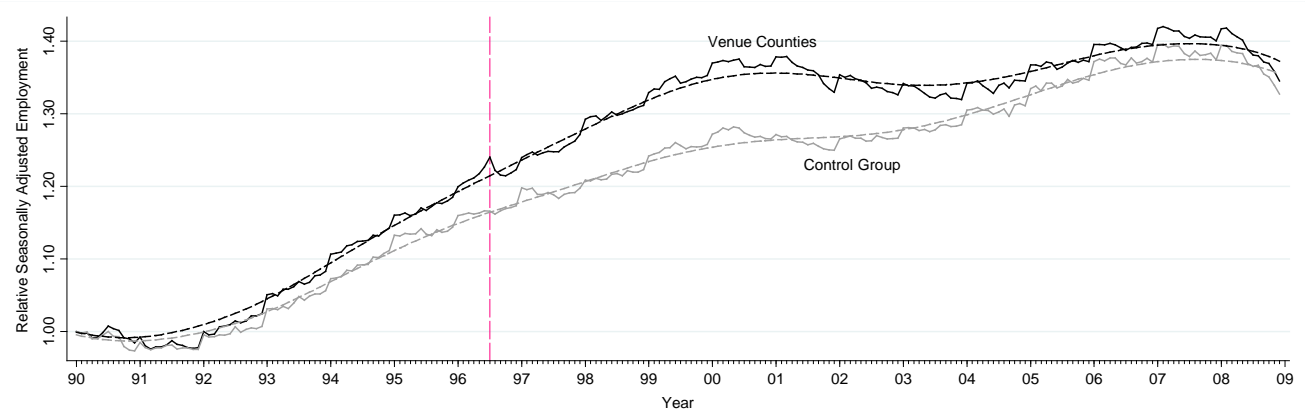




\section{Literature}

AHLFELDT, G. M. (2010). Blessing or Curse? Appreciation, Amenities and Resistance around the Berlin "Mediaspree": Hamburg Contemporary Economic Discussions, 32.

AHLFELDT, G. M., \& MAENNIG, W. (2008). Impact of Sports Arenas on Land Values: Evidence from Berlin. The Annals of Regional Science, 44(2), 205-227.

AHLFELDT, G. M., \& MAENNIG, W. (2009). Arenas, Arena Architecture and the Impact on Location Desirability: The Case of "Olympic Arenas" in Berlin-Prenzlauer Berg. Urban Studies, 46(7), 1343-1362.

ALLMERS, S., \& MAENNIG, W. (2009). Economic Impacts of the FIFA Soccer World Cups in France 1998, Germany 2006, and Outlook for South Africa 2010. Eastern Economic Journal, 35(4), 500-519.

ATLANTA COMMITTEE FOR THE OLYMPIC GAMES. (1997). The Official Report of the Centennial Olympic Game (Vol. 1, Planning and Organizing).

BAADE, R. A. (1996). Professional Sports as Catalysts for Metropolitan Economic Development. Journal of Urban Affairs, 18(1), 1-17.

BAADE, R. A., BAUMANN, R. W., \& MATHESON, V. A. (2008a). Selling the Game: Estimating the Economic Impact of Professional Sports through Taxable Sales. Southern Economic Journal, 74(3), 794-810.

BAADE, R. A., BAUMANN, R. W., \& MATHESON, V. A. (2008b). Slippery Slope? Assessing the Economic Impact of the 2002 Winter Olympic Games in Salt Lake City, Utah. Région \& Développement, 31, 79-89.

BAADE, R. A., BAUMANN, R. W., \& MATHESON, V. A. (2010). Big Men on Campus: Estimating the Economic Impact of College Sports on Local Economies. Regional Studies, DOI: 10.1080/00343400903241519 (iFirst, 21 January 2010).

BAADE, R. A., \& DYE, R. F. (1988). An Analysis of the Economic Rational for Public Subsidization of Sports Stadiums. Annals of Regional Science, 22(2), 37-47.

BAADE, R. A., \& DYE, R. F. (1990). The Impact of Stadiums and Professional Sports on Metropolitan Area Development. Growth and Change, 21(2), 1-14.

BAADE, R. A., \& MATHESON, V. A. (2001). Home Run or Wild Pitch? Assessing the Economic Impact of Major League Baseball's All-Star Game. Journal of Sports Economics, 2(4), 307-327.

BAADE, R. A., \& MATHESON, V. A. (2002). Bidding for the Olympics: Fool's Gold? In C. P. Barros, M. Ibrahimo, \& S. Szymanski (Eds.), Transatlantic Sport: The Comparative Economics of North American and European Sports (pp. 127-151). Cheltenham, U.K. and Northampton, Mass.: Edward Elgar.

BAADE, R. A., \& MATHESON, V. A. (2004). The Quest for the Cup: Assessing the Economic Impact of the World Cup. Regional Studies, 38(4), 343-354.

BAADE, R. A., \& SANDERSON, A. R. (1997). The Employment Effect of Teams and Sports Facilities. In R. G. Noll, \& A. Zimbalist (Eds.), Sports, Jobs, and Taxes: The Economic Impact of Sports Teams and Stadiums (pp. 92-118). Washington, D.C.: Brookings Institution Press.

BAIM, D. V. (1994). The Sports Stadium as a Municipal Investment. Westport and London: Greenwood Press.

BALTAGI, B. H. (2001). Econometric Analysis of Panel Data (2 ed.). New York: Wiley \& Sons. 
BAUMANN, R. W., MATHESON, V. A., \& MUROI, C. (2009). Bowling in Hawaii: Examining the Effectiveness of Sports-Based Tourism Strategies. Journal of Sports Economics, 10(1), 107-123.

BERTRAND, M., DUFLO, E., \& MULLAINATHAN, S. (2004). How Much Should We Trust Differences-in-Differences Estimates? Quarterly Journal of Economics, 119(1), 249-275.

BUREAU OF LABOR STATISTICS. (2009). Quarterly Census of Employment and Wages.

BUREAU OF LABOR STATISTICS (2010). County Employment and Wages Technical Note. Retrieved 4th Febuary 2010, from http://www.bls.gov/news.release/cewqtr.tn.htm.

CARLINO, G., \& COULSON, N. E. (2004). Compensating Differentials and the Social Benefits of the NFL. Journal of Urban Economics, 56(1), 25-50.

CITY OF ATLANTA (2010). Atl Fact Sheet. Retrieved 4th Febuary 2010, from http://www.atlanta-airport.com/Airport/ATL/ATL_FactSheet.aspx.

COATES, D. (2006). The Tax Benefits of Hosting the Super Bowl and the MLB All-Star Game: The Houston Experience. International Journal of Sport Finance, 1(4), 239-252.

COATES, D., \& DEPKEN II, C. A. (2006). Mega-Events: Is the Texas-Baylor Game to Waco What the Super Bowl Is to Houston? International Association of Sports Economists, Working Paper 0606.

COATES, D., \& HUMPHREYS, B. R. (1999). The Growth Effects of Sport Franchises, Stadia, and Arenas. Journal of Policy Analysis and Management, 18(4), 601-624.

COATES, D., \& HUMPHREYS, B. R. (2002). The Economic Impact of Postseason Play in Professional Sports. Journal of Sports Economics, 3(3), 291-299.

COATES, D., \& HUMPHREYS, B. R. (2003). The Effect of Professional Sports on Earnings and Employment in the Services and Retail Sectors in US Cities. Regional Science and Urban Economics, 33(2), 175-198.

COATES, D., \& HUMPHREYS, B. R. (2006). Proximity Benefits and Voting on Stadium and Arena Subsidies. Journal of Urban Economics, 59(2), 285-299.

COATES, D., \& HUMPHREYS, B. R. (2008). Do Economists Reach a Conclusion on Subsidies for Sports Franchises, Stadiums, and Mega-Events? Econ Journal Watch, 5(3), 294-315.

COATES, D., \& MATHESON, V. A. (2009). Mega-Events and Housing Costs: Raising the Rent While Raising the Roof? The Annals of Regional Science, DOI: 10.1007/s00168009-0340-5 (5 November 2009).

DACHIS, B., DURANTON, G., \& TURNER, M. A. (2010). The Effect of Land Transfer Taxes on Real Estate Markets: Evidence from a Natural Experiment in Toronto. Working Paper, Univertsity of Toronto (forthcoming in Journal of Urban Economics).

DAVIS, M. C., \& END, C. M. (2010). A Winning Proposition: The Economic Impact of Successful National Football League Franchises. Economic Inquiry, 48(1), 39-50.

ENDERS, W. (1995). Applied Econometric Time Series. New York: Wiley \& Sons.

FEDDERSEN, A., GRÖTZINGER, A. L., \& MAENNIG, W. (2009). Investment in Stadia and Regional Economic Development - Evidence from FIFA World Cup 2006. International Journal of Sport Finance, 4(4), 221-239.

FRENCH, S. P., \& DISHER, M. E. (1997). Atlanta and the Olympics: A One-Year Retrospective. Journal of the American Planning Association, 63(3), 379-392. 
GIUS, M., \& JOHNSON, D. (2001). An Empirical Estimation of the Economic Impact of Major League Sports Teams on Cities. Journal of Business \& Economic Studies, 7(1), 3238.

HAGN, F., \& MAENNIG, W. (2008). Employment Effects of the Football World Cup 1974 in Germany. Labour Economics, 15(5), 1062-1075.

HAGN, F., \& MAENNIG, W. (2009). Labour Market Effects of the 2006 Soccer World Cup in Germany. Applied Economics, 41(25), 3295-3302.

HALVORSEN, R., \& PALMOUIST, R. (1980). The Interpretation of Dummy Variables in Semilogarithmic Equations. American Economics Review, 70(3), 474-475.

HOTCHKISS, J. L., MOORE, R. E., \& ZOBAY, S. M. (2003). Impact of the 1996 Summer Olympic Games on Employment and Wages in Georgia. Southern Economic Journal, 69(3), 691-704.

IMBENS, G. W., \& LEMIEUX, T. (2008). Regression Discontinuity Designs: A Guide to Practice. Journal of Econometrics, 142(2), 615-635.

IOC (2010). Atlanta 1996. Retrieved 20 January 2010, from http://www.olympic.org/en/ content/Olympic-Games/All-Past-Olympic-Games/Summer/Atlanta-1996/.

JASMAND, S., \& MAENNIG, W. (2008). Regional Income and Employment Effects of the 1972 Munich Summer Olympic Games. Regional Studies, 42(7), 991-1002.

KAVETSOS, G., \& SZYMANSKI, S. (2009). National Well-Being and International Sports Events. Journal of Economic Psychology, DOI:10.1016/j.joep.2009.1011.1005.

KURSCHEIDT, M., PREUß, H., \& SCHÜTTE, N. (2008). Konsuminduzierter Impakt von Sportgroßevents am Beispiel der Fußball-WM 2006 - Befragungsergebnisse und Implikationen für die Euro 2008 [Consumption Induced Impact of Major Sport Events for the Case of the Football World Cup 2006: Survey Results and Implications for Euro 2008]. Wirtschaftspolitische Blätter, 55(1), 79-94.

LA84 FOUNDATION (2010). Past Olympic Games in the United States. Retrieved 20 January, 2010, from http://www.aafla.org/6oic/primer USgames.htm\#1996s.

LAVOIE, M., \& RODRIGUEZ, G. (2005). The Economic Impact of Professional Teams on Monthly Hotel Occupancy Rates of Canadian Cities: A Box-Jenkins Approach. Journal of Sports Economics, 6(3), 314-324.

LAYARD, R., NICKELL, S., \& JACKMAN, R. (2005). Unemployment: Macroeconomic Performance and the Labour Market (2 ed.). Oxford: Oxford University Press.

LEEDS, M. A. (2008). Do Good Olympics Make Good Neighbors? Contemporary Economic Policy, 26(3), 460-467.

LERTWACHARA, K., \& COCHRAN, J. J. (2007). An Event Study of the Economic Impact of Professional Sport Franchises on Local U.S. Economies. Journal of Sports Economics, 8(3), 244-254.

MARSH, L. C., \& CORMIER, D. R. (2001). Spline Regression Models. Sage University Paper Series on Quantitative Applications in Social Science, 07-137. Thousand Oaks, CA: Sage.

MATHESON, V. A. (2005). Contrary Evidence on the Economic Effect of the Super Bowl on the Victorious City. Journal of Sports Economics, 6(4), 420-428.

MILLER, P. A. (2002). The Economic Impact of Sports Stadium Construction: The Case of the Construction Industry in St. Louis, Mo. Journal of Urban Affairs, 24(2), 159-173. 
MUÑOZ, F. (1997). Historic Evolution and Urban Planning Typology of Olympic Villages. In M. De Moragas, M. Llinés, \& B. Kidd (Eds.), Olympic Villages: A Hundred Years of Urban Planning and Shared Experiences. Lausanne: International Olympic Committee.

NELSON, A. C. (2001). Prosperity or Bligth? A Question of Major League Stadia Locations. Economic Developmet Quarterly, 15(3), 255-265.

NGE (2010). Olympic Games in 1996. Retrieved 20 January, 2010, from http://www.georgiaencyclopedia.org/nge/Article.jsp?id=h-2042.

NICKELL, S. (1997). Unemployment and Labor Market Rigidities: Europe Versus North America. Journal of Economic Perspectives, 11(3), 55-74.

PORTER, P. K. (1999). Mega-Sports Events as Municipal Investments: A Critique of Impact Analysis. In J. Fizel, E. Gustafson, \& L. Hadley (Eds.), Sports Economics: Current Research (pp. 61-74). Westport, CT: Praeger Publishers.

PORTER, P. K., \& FLETCHER, D. (2008). The Economic Impact of the Olympic Games: Ex Ante Predictions and Ex Poste Reality. Journal of Sport Management, 22(4), 470-486.

SANTO, C. (2005). The Economic Impact of Sports Stadiums: Recasting the Analysis in Context. Journal of Urban Affairs, 27(2), 177-192.

STERKEN, E. (2006). Growth Impact of Major Sporting Events. European Sport Management Quarterly, 6(4), 375-389.

TU, C. C. (2005). How Does a New Sports Stadium Affect Housing Values? The Case of Fedex Field. Land Economics, 81(3), 379-395.

UNITED STATES GENERAL ACCOUNTING OFFICE. (2000). Olympic Games. Federal Government Proivides Significant Funding and Support. Report to Congressional Requesters, GAO/GGD-00-183. Washington D.C.

US CENSUS BUREAU. (2010). 2002 NAICS Codes and Titles [Electronic Version]. Retrieved January 18, 2009 from http://www.census.gov/epcd/naics02/naicod02.htm. 


\section{Hamburg Contemporary Economic Discussions}

(Download: http://www.uni-hamburg.de/economicpolicy/discussions.html)

01/2005 FEDDERSEN, A. / MAENNIG, W.: Trends in Competitive Balance: Is there Evidence for Growing Imbalance in Professional Sport Leagues?, January 2005.

02/2005 SIEVERS, T.: Information-driven Clustering - An Alternative to the Knowledge Spillover Story, February 2005.

03/2005 SIEVERS, T.: A Vector-based Approach to Modeling Knowledge in Economics, February 2005.

04/2005 BUETTNER, N. / MAENNIG, W. / MENSSEN, M.: Zur Ableitung einfacher Multiplikatoren für die Planung von Infrastrukturkosten anhand der Aufwendungen für Sportstätten - eine Untersuchung anhand der Fußball-WM 2006, May 2005.

01/2006 FEDDERSEN, A.: Economic Consequences of the UEFA Champions League for National Championships - The Case of Germany, May 2006.

02/2006 FEDDERSEN, A.: Measuring Between-season Competitive Balance with Markov Chains, July 2006.

03/2006 FEDDERSEN, A. / VÖPEL, H.: Staatliche Hilfen für Profifußballclubs in finanziellen Notlagen? - Die Kommunen im Konflikt zwischen Imageeffekten und Moral-Hazard-Problemen, September 2006.

04/2006 MAENNIG, W. / SCHWARTHOFF, F.: Stadium Architecture and Regional Economic Development: International Experience and the Plans of Durban, October 2006. 


\section{Hamburg Contemporary Economic Discussions}

(Download: http://www.uni-hamburg.de/economicpolicy/discussions.html)

01

02

03

04

05

06

07

08

O9

10

11

12

13

AHLFELDT, G. I MAENNIG, W.: The Role of Architecture on Urban Revitalization: The Case of "Olympic Arenas" in Berlin-Prenzlauer Berg, 2007.

FEDDERSEN, A. / MAENNIG, W. / ZIMMERMANN, P.: How to Win the Olympic Games - The Empirics of Key Success Factors of Olympic Bids, 2007.

AHLFELDT, G. / MAENNIG, W.: The Impact of Sports Arenas on Land Values: Evidence from Berlin, 2007.

DU PLESSIS, S. I MAENNIG, W.: World Cup 2010: South African Economic Perspectives and Policy Challenges Informed by the Experience of Germany 2006, 2007.

HEYNE, M. / MAENNIG, W. / SUESSMUTH, B.: Mega-sporting Events as Experience Goods, 2007.

DUST, L. / MAENNIG, W.: Shrinking and Growing Metropolitan Areas - Asymmetric Real Estate Price Reactions? The Case of German Single-family Houses, 2007.

JASMAND, S. / MAENNIG, W.: Regional Income and Employment Effects of the 1972 Munich Olympic Summer Games, 2007.

HAGN, F. / MAENNIG W.: Labour Market Effects of the 2006 Soccer World Cup in Germany, 2007.

HAGN, F. / MAENNIG, W.: Employment Effects of the World Cup 1974 in Germany.

MAENNIG, W.: One Year Later: A Re-appraisal of the Economics of the 2006 Soccer World Cup, 2007.

AHLFELDT, G., MAENNIG, W.: Assessing External Effects of City Airports: Land Values in Berlin, 2007.

AHLFELDT, G.: If Alonso was Right: Accessibility as Determinant for Attractiveness of Urban Location, 2007.

AHLFELDT, G.: A New Central Station for a Unified City: Predicting Impact on Property Prices for Urban Railway Network Extension, 2007. 


\section{Hamburg Contemporary Economic Discussions}

(Download: http://www.uni-hamburg.de/economicpolicy/discussions.html)

FEDDERSEN, A. / MAENNIG, W.: Arenas vs. Multifunctional Stadia Which Do Spectators Prefer?, 2007.

AHLFELDT, G. / FEDDERSEN, A.: Geography of a Sports Metropolis, 2007.

FEDDERSEN, A. / GRÖTZINGER, A. / MAENNIG, W.: New Stadia and Regional Economic Development - Evidence from FIFA World Cup 2006 Stadia, 2008.

AHLFELDT, G. / MAENNIG, W.: Monumental Protection: Internal and External Price Effects, 2008.

MAENNIG, W. / PORSCHE, M.: The Feel-good Effect at Mega Sport Events - Recommendations for Public and Private Administration Informed by the Experience of the FIFA World Cup 2006, 2008.

AHLFELDT, G.: The Train has Left the Station: Real Estate Price Effects of Mainline Realignment in Berlin, 2008.

MAENNIG, W. / WELLBROCK, C.-M.: Sozio-ökonomische Schätzungen Olympischer Medaillengewinne: Analyse-, Prognose- und Benchmarkmöglichkeiten, 2008.

MAENNIG, W. / ALLERMS, S.: South Africa 2010: Economic Scope and Limits, 2008.

AHLFELDT, G. / FEDDERSEN, A.: Determinants of Spatial Weights in Spatial Wage Equations: A Sensitivity Analysis, 2008.

AHLFELDT, G. / WENDLAND, N.: Fifty Years of Urban Accessibility: The Impact of Urban Railway Network on the Land Gradient in Industrializing Berlin, 2008.

AHLFELDT, G. / FRANKE, B. / MAENNIG, W.: Terrorism and the Regional and Religious Risk Perception of Foreigners: The Case of German Tourists, 2009.

FEDDERSEN, A. / MAENNIG, W.: Wage and Employment Effects of the Olympic Games in Atlanta 1996 Reconsidered, 2009.

AHLFELDT, G. I MAENNIG, W.: Impact of Non-Smoking Ordinances on Hospitality Revenues: The Case of Germany, 2009. 


\section{Hamburg Contemporary Economic Discussions}

(Download: http://www.uni-hamburg.de/economicpolicy/discussions.html)

BJФRNSKOV , C. / DREHER, A. / FISCHER, J.A.V. / SCHNELLENBACH, J.: On the Relation Between Income Inequality and Happiness: Do Fairness Perceptions Matter?, 2009.

AHLFELDT, G. / MAENNIG, W. / OSTERHEIDER, T.: Regional and sectoral effects of a common monetary policy: evidence from Euro Referenda in Denmark and Sweden, 2009.

FEDDERSEN, A. / JACOBSEN, S. / MAENNIG, W.: Sports Heroes and Mass Sports Participation - The (Double) Paradox of the "German Tennis Boom", 2009.

AHLFELDT, G. / MAENNIG, W. / ÖLSCHLÄGER, M.: Lifestyles and Preferences for (Public) Goods: Professional Football in Munich, 2009.

FALCH, T. / FISCHER, J.A.V.: Public Sector Decentralization and School Performance: International Evidence, 2010.

AHLFELDT, G.: Blessing or curse? Appreciation, Amenities, and Resistance around the Berlin "Mediaspree", 2010.

FEDDERSEN, A. / MAENNIG, W.: Sectoral Labor Market Effects of the 2006 FIFA World Cup, 2010.

FISCHER, J.A.V.: The Impact of Institutions on Firms' Rejuvenation Policies: Early Retirement with Severance Pay versus Simple Lay-Off. A Cross-European Analysis, 2010.

FEDDERSEN, A. / MAENNIG, W.: Mega-Events and Sectoral Employment: The Case of the 1996 Olympic Games, 2010. 


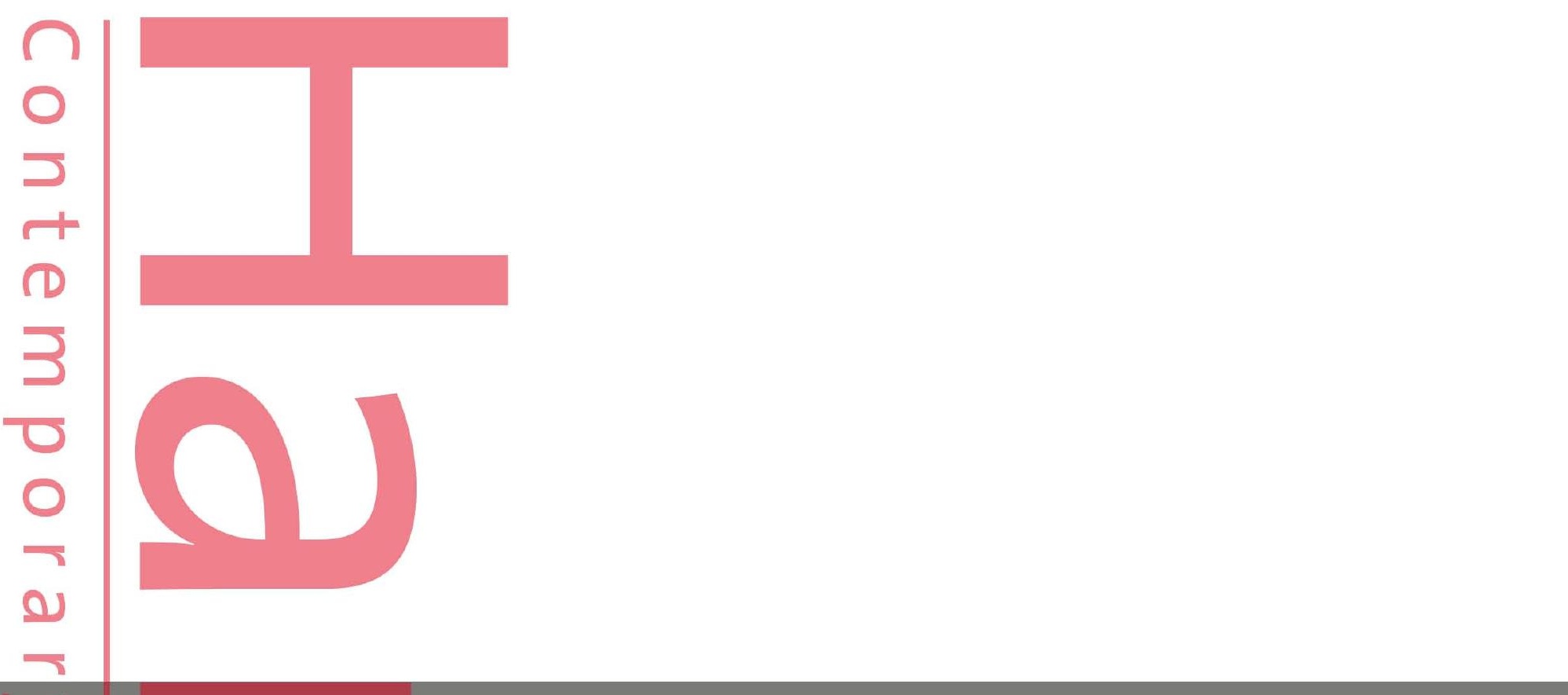

ISSN 1865-2441 (PRINT) ISSN $1865-7133$ (ONLINE)

ISBN 978-3-940369-84-O (PRINT) ISBN 978-3-940369-85-7 (ONLINE) 